\title{
Mutual Fund Governance: Does a Long-term Relationship with Managers Blind Directors?
}

\author{
by \\ Anh Tran
}

Submitted in Partial Fulfillment of the

Requirements for the Degree

Doctor of Philosophy

Supervised by

Professor Ron Kaniel

and

Professor Jerold Warner

Business Administration

Simon School of Business

University of Rochester

Rochester, New York 
Dedicated to my mothers. 


\section{Table of Contents}

Biographical Sketch $\quad$ v

Acknowledgments $\quad$ vi

Abstract vii

Contributors and Funding Sources viii

List of Tables $\quad$ x

List of Figures $\quad$ xi

1 Introduction 1

2 Data and Measurement 6

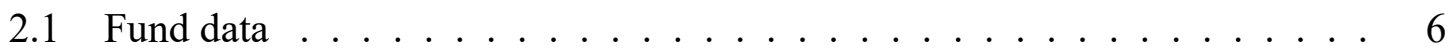

2.2 Manager data . . . . . . . . . . . . . . . . . 7

2.3 Director data . . . . . . . . . . . . . . . . 8

2.4 Sample and summary statistics . . . . . . . . . . . . . 10 
4 Manager survivorship in relation to their connection with fund independent directors

5 Hiring managers who have a tight connection with fund directors

5.1 Sample selections and summary statistics . . . . . . . . . . . 30

5.2 Fund performance when hiring connected versus non-connected managers . 34

5.3 Fund performance when hiring Hiring-Teammate managers . . . . . . . . . 35

5.4 Fund performance when hiring Boomerang managers . . . . . . . . . . . 41

5.4.1 Fund and manager performance during the first term . . . . . . . 41

5.4.2 Fund performance during the second term . . . . . . . . . 45

6 Conclusions 


\section{Biographical Sketch}

Anh Tran grew up in Ho Chi Minh City, Vietnam and received his Bachelor of Engineering degree in Automotive Engineering from Ho Chi Minh City University of Technology in 2006. He attended the University of Utah and graduated with a Master of Science degree in Finance in 2011. In the summer of 2012, he enrolled in the Business Administration doctoral program at the University of Rochester Simon Business School. He received a doctoral student fellowship from 2012 to 2016 and earned a Master of Science degree in Business Administration in 2015. His research in empirical asset pricing and empirical corporate finance was conducted under the supervision of Professors Ron Kaniel and Jerold Warner. 


\section{Acknowledgments}

I would like to express my sincere gratitude to my co-advisor Ron Kaniel for his continuous guidance, encouragement, and support. I am thankful to him for his genuine care and kindness. I am also deeply indebted to my co-advisor Jerold Warner and committee member John Long for their invaluable comments and timely suggestions. I would also like to thank Simon faculty members Sudarshan Jayaraman, Alan Moreira, Bryce Schonberger, and Bill Schwert for helpful comments and suggestions. 


\section{Abstract}

This paper studies how the strengthening of social ties between fund independent directors and fund managers affects fund governance. By using the duration of past employment in which they worked together as a proxy for the effort independent directors put into monitoring and governing the funds, I find that the longer managers are connected with independent directors, the lower their funds perform. In addition, manager entrenchment emerges when he/she has a longer duration of connection with independent directors. Managers with longer connection duration have a lower hazard of turning over, even in the periods when funds have a negative past 3-year performance. This negative effect is significantly greater in funds especially owned by retail investors. Furthermore, managers who have a significant relationship with fund independent directors have no risk from poor performance. Finally, newly hired managers who are well-connected with their fund directors will do more harm than good for investors. 


\section{Contributors and Funding Sources}

The work in this dissertation has been conducted independently without outside funding support, under the supervision of Professors Ron Kaniel, John Long, and Jerold Warner of the Department of Finance at the Simon Business School and Professor Kevin Clarke of the Department of Political Science at the University of Rochester. Graduate study was supported by a doctoral student fellowship from the Simon Business School. 


\section{List of Tables}

2.1 Summary statistics for unconstrained sample - periods 1996/01 to 2015/12. 9

2.2 Summary statistics for subsample - periods $1996 / 01$ to $2015 / 12$. . . . . . . 11

3.1 Fund performance and director-manager connection duration: Regression evidence. ........................... 15

4.1 Cox proportional hazard model of turnover. . . . . . . . . . . . . . 21

5.1 Summary statistics for funds and managers before new hires. . . . . . . . . 31

5.2 Fund performance when hiring connected versus non-connected managers. 35

5.3 Fund performance when hiring managers who were/are co-managers with fund's directors at other funds. . . . . . . . . . . . . . 36

5.4 Propensity score matching and performance comparison for Hiring-Teammate

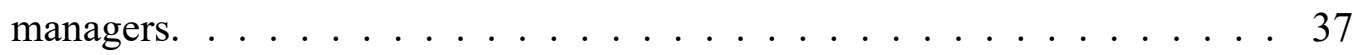

5.5 Performance of Boomerang managers at the first employment. . . . . . . . 42

5.6 Performance of Boomerang managers at the second employment. . . . . . . 46 
5.7 Propensity score matching and performance comparison for Boomerang managers at the second employment. . . . . . . . . . . . . . . . . 48 


\section{List of Figures}

4.1 Manager survivorship. . . . . . . . . . . . . . . . . . . . . 24

4.2 Cox hazard model: Sensitivity of Connection Duration on key variables. 25

5.1 Time line when funds hire Hiring-Teammate and Boomerang managers. . . 29 


\section{Chapter 1}

\section{Introduction}

Independent directors are crucial to both corporate governance and mutual fund governance. They have a fiduciary duty to look after investors' interests. However, there is mixed evidence on whether funds or firms with more independent directors are linked to better performance. If we take into account social connections between independent directors and chief executive officers (CEO) or fund managers, such as education, prior and current employments, etc., to reclassify independent directors, it is still unclear whether independent directors improve governance (Fracassi and Tate (2012), Hwang and Kim (2009), Chidambaran et al. (2012), Khanna et al. (2015), Bruynseels and Cardinaels (2014), and Crespi-Cladera and Pascual-Fuster (2014)). In this paper, I study how the intensity of the connection between independent directors and fund managers affects fund governance by looking at fund performance, and hiring and firing decisions.

This paper focuses on the U.S. open-end mutual fund industry because the performance of managers in mutual funds is easier to measure than that in corporate firms. In addition, directors of mutual funds share similar duties with those from traditional corporate boards, 
such as overseeing the management and operations (electing officers, appointing committees, serving on audit committees, serving on nominating committees, approving mergers or other transactions, overseeing the performance, etc.) of the fund on behalf of the fund's shareholders. Unlike directors of corporate boards, those of mutual funds do not plan the fund's strategy and future direction. However, this duty is out of the scope of this paper, which focuses on the director's monitoring responsibilities.

I argue that the level of independence of independent directors is likely to erode over time as social ties between fund independent directors and fund managers strengthen. Hence, I propose that the longer independent directors and managers are connected, the less effort the directors put into monitoring the fund, leading to a decline in fund governance over time. The connection duration between inside directors and managers is less likely to affect fund governance since inside directors are either employees of the fund's adviser or members of the immediate family of an employee; thus, their interests are more aligned with the fund's managers than the fund's investors. To test this hypothesis, I use a data set of 3,170 U.S. actively managed equity funds, monitored and managed by 4,526 directors and 5,921 managers, covering the period from 1996 through 2015. This is the largest constructed sample to date, in terms of the number of funds as well as the time span, that contains fund board characteristics. I found that the connection duration between managers and independent (inside) directors is negatively (not) related to fund future performance. More specifically, for median funds, each additional 1-year connection between managers and independent directors lowers fund net abnormal returns by about $0.04 \%$ per year. This deteriorative per- 
formance persists regardless of whether funds are managed by individual managers or by teams, or whether funds are outsourced or managed in house.

To increase the independence and effectiveness of fund boards, the Securities and Exchange Commission (SEC) raised the minimum percentage of independent directors from $40 \%$ in 1999 to $75 \%$ in 2004 . However, there is mixed evidence that funds with more independent directors are linked to better performance. Adams et al. (2010) show that funds governed exclusively by independent directors have superior performance, while Meschke (2007) shows that board independence negatively affects fund returns. In addition, Guercio et al. (2003), Ferris and Yan (2007), Ding and Wermers (2012), and Adams et al. (2016) document that the fraction of independent directors is not related to fund performance. The results in this paper confirm these previous findings, that the fraction of independent directors does not affect fund performance. These results raise the concern of the effectiveness of the SEC proposal to increase the number of independent directors per board, and ask for more sophisticated definition of independent directors. I also found that larger boards are associated with lower performance (Guercio et al. (2003) and Adams et al. (2010)). Moreover, since, on average, directors oversee 45 funds at a given time (much higher than those who sit on a corporate board with only 1.29 firms on average, Chu and Davis (2016)), their ability to monitor and govern the funds may decline. However, similar to Adams et al. (2010), I found that the number of funds overseen by directors does not affect fund performance.

Next, I show that there is manager entrenchment when the connection duration between 
managers and independent directors increases. Managers will have significantly longer tenure when they have a longer connection duration with the fund's independent directors. Specifically, all else being equal, compared to managers with a 1-year connection with independent directors, those with a 5-year connection have a lower hazard (29\%) of turn over. However, connection duration with inside directors does not affect manager's turn over. The results also suggest that a long-term relationship with independent directors increases the manager's chance of staying at the funds longer even when funds perform badly. In addition, this positive relationship is even stronger in funds with weaker external governance, that is proxied by a low fraction of institutional investors.

Finally, hiring managers who have both a long-term and tight relationship with the directors is bad for investors. Managers have a tight connection with directors when [1] they are/were co-managers at other funds (Hiring-Teammate sample), or when [2] funds re-hire managers who worked there before (Boomerang sample). In addition, these funds generally have weak governance, such as a low fraction of independent directors and a low fraction of institutional ownership. One may attribute bad fund performance from these hirings to weak governance. However, compared to matched funds, on both newly hired managers' and funds' characteristics, funds that hire Hiring-Teammate (Boomerang) managers underperformed by $0.12 \%(0.09 \%)$ per month. In addition, the difference in change in performance between pre- and post-turnover events is also significantly lower by $0.16 \%$ $(0.12 \%)$ per month.

The remainder of this paper is organized as follows. Section 2 describes the data and the 
measurement of connection duration. Section 3 studies the relationship between fund performance and the connection duration between managers and fund independent directors. Section 4 examines manager survivorship. Section 5 analyzes the cost/benefit of hiring managers with a tight connection. Section 6 provides final conclusions. 


\section{Chapter 2}

\section{Data and Measurement}

\subsection{Fund data}

The sample is the combined data from the Center for Research in Security Prices (CRSP) survivorship bias free mutual fund database and the Morningstar Direct database. Fund share classes from these two databases are merged by using their tickers, cusip, or names if both tickers and cusip are missing ${ }^{1}$. Then expense ratios, total net assets (TNA), and returns at share class level are aggregated to one fund level observations using their previous month TNA as weights. Fund TNA are the sum of TNA of all share classes within the same fund. All index funds, non-equity funds, and fund observations are dropped before TNA reach $\$ 5$ million. In addition, only funds managed by managers who first appeared in both CRSP and Morningstar databases since 1996 are retained, since we can only get fund board directors' identification from Securities and Exchange Commission (SEC) starting in 1996 to build the director-manager connection variables. The final sample includes 3,170 U.S. actively managed equity funds, covering the period from January 1996 to December 2015.

\footnotetext{
${ }^{1}$ CRSP-Morningstar Direct merging procedure is available upon request.
} 


\subsection{Manager data}

Both databases have manager identities, but Morningstar Direct provides a cleaner and more complete list of managers for each fund. Not as consistent as manager names in Morningstar Direct, those in CRSP are sometimes recorded missing either first or last names. These incomplete names are corrected using names from Morningstar Direct for funds that appear in both databases. This procedure identifies 5,921 managers present in both databases starting in 1996 who work for 3,170 funds.

Manager's characteristics, such as gender, education background (degrees and schools where and when degrees are received), Chartered Financial Analyst (CFA) designation and date, are from Morningstar Direct (primarily), LinkedIn, fund prospectuses, and fund webpages. Manager's Scholastic Aptitude Test (SAT) is constructed following the methodology of Chevalier and Ellison (1999). First, I obtained the SAT score from the undergraduate institution (or graduate one, if the undergraduate is not available) for each manager from multiple sources ${ }^{2}$. The manager SAT score is the sum of the average of the $25^{\text {th }}$ and $75^{\text {th }}$ percentile verbal score and the average of the $25^{\text {th }}$ and $75^{\text {th }}$ percentile math score. For schools that ask for the ACT score instead of the SAT scores, the ACT score is converted to SAT using SAT-ACT conversion tables from CollegeBoard ${ }^{3}$.

\footnotetext{
${ }^{2}$ http://www.powerscore.com, http://www.collegesimply.com, and http://www. prepscholar.com

${ }^{3}$ https://research.collegeboard.org
} 


\subsection{Director data}

I obtained board directors' names and their independent status for each fund-year from the Statement of Additional Information (SAI) in the 485APOS or 485BPOS form filed by funds with the SEC. To correctly build a director-manager network for the 5,921 managers, I collected 485APOS or 485BPOS forms for all index and actively managed funds, regardless of their TNA, by searching fund share class's tickers or names on the SEC's Edgar database. I kept only funds that are managed by managers in my sample. I also kept all funds that are monitored by directors who sit on the board of my sample funds (this is to count total number of funds these directors sit on at each period). Table 2.1 presents the summary statistics on the director-manager network of 5,921 managers and 4,526 directors. The sample used in this statistic contains 79,600 fund-year prospectuses of 6,849 funds and only managers who first appeared in the CRSP and Morningstar database after 1996. On average, a director sits on 20 different fund boards and oversees 54 managers while a manager typically reports to 23 directors over their tenure. A total of 128,023 pairs of directors and managers work for the same fund on average of 41 months $^{4}$.

\footnotetext{
${ }^{4}$ Since funds only file $485 \mathrm{APOS} / 485 \mathrm{BPOS}$ forms once a year, monthly board information is forwardly filled from year $t$ filing date to next year filling date.
} 


\section{Table 2.1}

Summary statistics for unconstrained sample - periods 1996/01 to 2015/12.

This table reports summary statistics for major variables of director-manager network. Sample includes 6,849 U.S. index and actively managed equity funds, regardless of fund size, that managed by only managers who first appeared in the CRSP and Morningstar database after $1996 / 01$.

\begin{tabular}{|c|c|c|c|c|c|c|c|c|c|c|}
\hline At fund_year level & \# fund_year & mean & median & $\mathrm{sd}$ & $\min$ & 5 pct & $25 \mathrm{pct}$ & $75 \mathrm{pct}$ & $95 \mathrm{pct}$ & $\max$ \\
\hline Board size & 79,600 & 8 & 8 & 3 & 1 & 3 & 5 & 10 & 13 & 17 \\
\hline At director level & \# directors & mean & median & $\mathrm{sd}$ & $\min$ & 5 pct & $25 \mathrm{pct}$ & $75 \mathrm{pct}$ & $95 \mathrm{pct}$ & $\max$ \\
\hline Number of managers that directors monitored & 4,526 & 54 & 26 & 74 & 1 & 2 & 9 & 70 & 199 & 838 \\
\hline $\max ($ number of funds in a given month) director monitored & 4,526 & 20 & 11 & 27 & 1 & 1 & 5 & 26 & 62 & 277 \\
\hline At manager level & \# managers & mean & median & $\mathrm{sd}$ & $\min$ & 5 pct & $25 \mathrm{pct}$ & $75 \mathrm{pct}$ & $95 \mathrm{pct}$ & $\max$ \\
\hline Number of directors managers reported & 5,921 & 23 & 16 & 20 & 3 & 5 & 10 & 28 & 63 & 211 \\
\hline At manager_director level & \# manager_director & mean & median & $\mathrm{sd}$ & $\min$ & 5 pct & $25 \mathrm{pct}$ & $75 \mathrm{pct}$ & $95 \mathrm{pct}$ & $\max$ \\
\hline $\max$ (number of months they worked under the same fund) & 128,023 & 41 & 31 & 35 & 1 & 3 & 14 & 57 & 111 & 238 \\
\hline
\end{tabular}




\subsection{Sample and summary statistics}

Table 2.2 shows the descriptive statistics on the final sample. There are 5,921 managers with the average tenure of 4 years managing 3,170 funds with average age of 10 years, TNA of $\$ 763$ million, monthly expense ratio of $0.1 \%$, and monthly net alpha of $-0.1 \%$ (using Fama and French (1993) and Carhart (1997) 4-factor model). The average monthly flow rate is $0.97 \%$. This is the ratio of $T N A_{t}-T N A_{t-1}\left(1+R_{t}\right)$ to $T N A_{t-1}$ where $R_{t}$ is fund return. Flow rate is winsorized at the $1 \%$ level to remove errors, such as mutual fund mergers and splits, as documented by Elton et al. (2001). The average percentage of institutional ownership is $27 \%$. Fund share-class types and share-class TNA are used to compute the fraction of funds owned by institutional investors. About $44 \%$ of funds are outsourced to outside advisors and about $40 \%$ of funds are managed by a single manager; the remaining are managed by a team of 3 managers on average. The median number of directors per board is 8 , and the average number of funds managed by directors within one board is 45 . 
Table 2.2

Summary statistics for subsample - periods $1996 / 01$ to $2015 / 12$.

This table reports summary statistics for only funds with total net asset larger than 5 million dollars and managed by managers who first appear in the database since 1996/01. Connection_ALL is the connection duration between managers and all directors of the fund. Connection_IND (Connection_DEP) is the connection duration between managers and independent (dependent or inside) directors. Fraction independent director is the ratio of number of independent directors to board size. Board size is the number of board directors work for a fund. Fraction institutional ownership is the fraction of fund owned by institutional investors. Number of funds is the average number of funds overseen by directors. Manager tenure is manager tenure within a fund. Fund age is fund age since inception. Team size is the number of managers co-manage the fund. SubAdvisor dummy, which is equal to 1 if funds are outsourced. Fund size is fund's total net assets. Fund expense is fund's expense ratio. Fund alpha is fund Cahart 4-factor net abnormal return. Fund flow rate is fund flow rate.

\begin{tabular}{lcccccccc}
\hline Variables & $\mathrm{N}$ & mean & median & $\mathrm{sd}$ & $\mathrm{p} 1$ & $\mathrm{p} 25$ & $\mathrm{p} 75$ & $\mathrm{p} 99$ \\
\hline Connection_ALL (month) & 268,537 & 4.27 & 1.52 & 10.15 & 0.04 & 0.66 & 3.54 & 49.00 \\
Connection_IND (month) & 268,537 & 4.20 & 1.53 & 9.93 & 0.04 & 0.67 & 3.60 & 48.50 \\
Connection_DEP (month) & 268,537 & 3.78 & 0.90 & 11.03 & 0.00 & 0.24 & 2.57 & 58.00 \\
Fraction independent director & 268,537 & 0.81 & 0.82 & 0.14 & 0.33 & 0.75 & 0.89 & 1.00 \\
Board size & 268,537 & 8.38 & 8 & 3.02 & 3 & 6 & 10 & 16 \\
Fraction institutional ownership & 268,537 & 0.27 & 0.02 & 0.37 & 0 & 0 & 0.51 & 1 \\
Number of funds & 268,537 & 45.14 & 31 & 49.52 & 1 & 14 & 52 & 221 \\
Manager tenure (year) & 268,537 & 4.06 & 3.33 & 3.02 & 0.25 & 1.83 & 5.56 & 13.92 \\
Fund age (year) & 268,537 & 10.13 & 7.83 & 8.98 & 0.33 & 3.58 & 14.00 & 46.33 \\
Team size & 268,537 & 2.26 & 2 & 1.52 & 1 & 1 & 3 & 8 \\
SubAdvisor dummy & 268,537 & 0.44 & 0 & 0.50 & 0 & 0 & 1 & 1 \\
Fund size (million) & 268,537 & 763 & 174 & 2,109 & 5 & 46 & 640 & 9,807 \\
Fund expense (\%) & 268,537 & 0.10 & 0.10 & 0.04 & 0.01 & 0.08 & 0.12 & 0.22 \\
Fund alpha (\%) & 268,537 & -0.10 & -0.08 & 2.44 & -7.14 & -1.09 & 0.88 & 7.07 \\
Fund flow rate (\%) & 268,537 & 0.97 & -0.16 & 7.21 & -15.85 & -1.36 & 1.60 & 34.71 \\
\hline
\end{tabular}

For fund $i$ at time $t$, the connection durations between managers and all directors (Connection_ALL), independent directors (Connection_IND), or dependent (or inside) directors 
(Connection_DEP) of the fund are calculated as below ${ }^{5}$ :

$$
\begin{aligned}
\text { Connection_ } \Theta_{i, t-1} & =\frac{1}{M_{i t}} \sum_{m \in \Omega_{i t}} \text { Connection_ } \Theta_{m i, t-1} \\
\text { Connection_ } \Theta_{m i, t-1} & =\frac{1}{D_{i t}^{\Theta}} \sum_{d \in \Gamma_{i t}^{\Theta}} W_{m d, t-1}, \quad \Theta=\{A L L, I N D, D E P\} \\
W_{m d, t-1} & =\sum_{j=1}^{t-1} \frac{\mathbf{1}(m, d, j)}{N_{d j}} \\
\mathbf{1}(m, d, j) & =\left\{\begin{array}{cc}
1, & \text { if manager } m \text { and director } d \text { worked at the } \\
& \text { same fund at time } j, \\
0, & \text { if otherwise. }
\end{array}\right.
\end{aligned}
$$

where $W_{m d, t-1}$ is total number of month manager $m$ and director $d$ have worked at the same funds (including fund $i$ and any others) up to time $t-1$. This value takes into account the number of funds that directors oversee at any given time $\left(N_{d j}\right)$, since directors who oversee more funds will have less interaction with managers whom they monitor. The relationship between manager $m$ and director $d$ at other funds except fund $i$ can be managerdirector, manager-manager, or director-director. If the relationships are manager-manager or director-director at time $t, N_{d t}$ is set equal to 1 even if $N_{d t}>1 . \Omega_{i t}$ is the set of managers who manage fund $i$ at $t$, and $M_{i t}$ is total number of managers. $\Gamma_{i t}^{I N D}\left(\Gamma_{i t}^{D E P}\right)$ is the set of independent (dependent or inside) directors in fund $i$ at $t$, and $D_{t}^{I N D}\left(D_{t}^{D E P}\right)$ is total number of independent (inside) directors. Under the Investment Company Act of 1940,

\footnotetext{
${ }^{5}$ The results in this paper are unchanged if the connection duration in Equation 2.1 is computed using manager tenure as the weights.
} 
to be classified as an independent director, he/she cannot be an employee of the fund's adviser or a member of the immediate family of an employee, be an employee or a 5-percent shareholder of a registered broker-dealer, or have an affiliation with any recent legal counsel to the fund. Table 2.2 shows that the average fraction of independent directors per board is $81 \%$ and the average connection duration between managers and independent (inside) directors is four months (four months). 


\section{Chapter 3}

\section{Fund performance}

One of the main duties of the board directors is to monitor and evaluate whether fund performance is satisfactory. If funds underperform their benchmark, independent directors need to strengthen the monitoring process and look closely at whether the investment process is consistent with the fund investment strategies, such as turnover, transaction costs, portfolio structure, risk, etc. However, independent directors may put less effort to undertake their duty when they have a longer connection duration with fund managers. This weak governance will translate to low fund performance. In addition, since inside directors are either employees of the fund's adviser or members of the immediate family of an employee, their interests are more aligned with the fund's managers rather than the fund's investors. Hence, fund performance may not be affected by their connection duration with fund managers.

Hypothesis 1 Connection duration between fund managers and fund independent (inside) directors is negatively (not) related to fund performance. 
To test this, I run the following panel regression:

$$
\begin{aligned}
\alpha_{i t}=\beta_{1} \ln \left(\text { Connection_IND } D_{i, t-1}+1\right) & +\beta_{2} \ln \left(\text { Connection_DEP }_{i, t-1}+1\right) \\
& +\gamma \mathbf{X}_{\mathbf{i}, \mathbf{t}-\mathbf{1}}+\lambda_{t}+\lambda_{i}+\varepsilon_{i t}
\end{aligned}
$$

where $\alpha_{i t}$ is Carhart 4-factor net abnormal return of fund $i$ at time $t$; Connection $_{i, t-1}$ is the connection duration between managers and fund directors defined in Equation $2.1 ; \mathbf{X}_{\mathbf{i}, \mathbf{t}-\mathbf{1}}$ includes fund and manager characteristics, such as fraction independent directors, board size, fund's fraction institutional ownership, logarithm of average number of funds managed by directors of fund, team size, logarithm of manager tenure, logarithm of fund age, fund net alpha, size, expense ratio, and flow rate; $\lambda_{t}$ and $\lambda_{i}$ are time and fund fixed effects. Standard errors are clustered at firm level. The hypothesis expects that coefficient $\beta_{1}$ should be negative and that coefficient $\beta_{2}$ should be equal to zero.

\section{Table 3.1}

Fund performance and director-manager connection duration: Regression evidence.

This table reports results for pool-panel regressions of fund next month net abnormal returns (Fund alpha, using 4-factor model) on: $A L L$ is logarithm of one plus connection duration (in years) between managers and all directors of the fund; IND $(D E P)$ is logarithm of one plus connection duration (in years) between managers and independent (dependent) directors of the fund; Fraction ind. director is the ratio of number of independent directors to board size. Board size is the number of directors sitting on fund board; Fraction inst. ownership is fraction of fund owned by institutional investors; Number of funds is logarithm of average number of funds overseen by directors; Team size is the number of managers who co-manage the fund; Manager tenure is logarithm of manager tenure within a fund (in years) plus one; Fund age is logarithm fund age in years; Fund size is logarithm of total fund net assets; Fund expense is fund total expense ratio; SubAdvisor is a dummy equal 1 if funds are outsourced. Standard errors clustered at the family level are in parentheses and ${ }^{*},{ }^{* *},{ }^{* * *}$ indicate significance at the $10 \%, 5 \%$, and $1 \%$ levels respectively. 
Table 3.1 (continued)

\begin{tabular}{|c|c|c|c|c|c|c|}
\hline & \multicolumn{6}{|c|}{ Fund alpha ${ }_{t}(\%)$} \\
\hline & (1) & (2) & (3) & (4) & (5) & (6) \\
\hline $\mathrm{ALL}_{t-1}$ & $\begin{array}{c}-0.169^{* * *} \\
(0.062)\end{array}$ & & & & & \\
\hline $\mathrm{DEP}_{t-1}$ & & $\begin{array}{c}-0.021 \\
(0.057)\end{array}$ & & & & \\
\hline $\mathrm{IND}_{t-1}$ & & $\begin{array}{c}-0.127^{* *} \\
(0.064)\end{array}$ & $\begin{array}{r}-0.120 \\
(0.087)\end{array}$ & $\begin{array}{c}-0.173^{* *} \\
(0.076)\end{array}$ & $\begin{array}{c}-0.213^{* *} \\
(0.103)\end{array}$ & $\begin{array}{c}-0.153^{* *} \\
(0.072)\end{array}$ \\
\hline $\mathrm{IND}_{t-1} \times$ Team size ${ }_{t-1}$ & & & $\begin{array}{r}-0.012 \\
(0.036)\end{array}$ & & & \\
\hline $\mathrm{IND}_{t-1} \times$ SubAdvisor & & & & $\begin{array}{c}0.092 \\
(0.093)\end{array}$ & & \\
\hline $\mathrm{IND}_{t-1} \times$ Board size $_{t-1}$ & & & & & $\begin{array}{c}0.014 \\
(0.018)\end{array}$ & \\
\hline $\mathrm{IND}_{t-1} \times$ Inst. ownership ${ }_{t-1}$ & & & & & & $\begin{array}{c}0.049 \\
(0.136)\end{array}$ \\
\hline Fraction ind. director ${ }_{t-1}$ & $\begin{array}{c}-0.122 \\
(0.083)\end{array}$ & $\begin{array}{c}-0.127 \\
(0.086)\end{array}$ & $\begin{array}{r}-0.120 \\
(0.083)\end{array}$ & $\begin{array}{c}-0.118 \\
(0.083)\end{array}$ & $\begin{array}{c}-0.118 \\
(0.083)\end{array}$ & $\begin{array}{c}-0.120 \\
(0.083)\end{array}$ \\
\hline Board size $_{t-1}$ & $\begin{array}{c}-0.014^{* * *} \\
(0.005)\end{array}$ & $\begin{array}{c}-0.014^{* * *} \\
(0.005)\end{array}$ & $\begin{array}{c}-0.014^{* * *} \\
(0.005)\end{array}$ & $\begin{array}{c}-0.014^{* * *} \\
(0.005)\end{array}$ & $\begin{array}{c}-0.016^{* * *} \\
(0.005)\end{array}$ & $\begin{array}{c}-0.014^{* * *} \\
(0.005)\end{array}$ \\
\hline Fraction inst. ownership $p_{t-1}$ & $\begin{array}{c}0.064 \\
(0.059)\end{array}$ & $\begin{array}{c}0.063 \\
(0.059)\end{array}$ & $\begin{array}{c}0.064 \\
(0.059)\end{array}$ & $\begin{array}{c}0.064 \\
(0.059)\end{array}$ & $\begin{array}{c}0.063 \\
(0.059)\end{array}$ & $\begin{array}{c}0.054 \\
(0.062)\end{array}$ \\
\hline Number of funds $s_{t-1}$ & $\begin{array}{c}0.034 \\
(0.036)\end{array}$ & $\begin{array}{c}0.036 \\
(0.037)\end{array}$ & $\begin{array}{c}0.036 \\
(0.037)\end{array}$ & $\begin{array}{c}0.037 \\
(0.036)\end{array}$ & $\begin{array}{c}0.038 \\
(0.037)\end{array}$ & $\begin{array}{c}0.037 \\
(0.037)\end{array}$ \\
\hline Team size $_{t-1}$ & $\begin{array}{c}-0.015^{* *} \\
(0.007)\end{array}$ & $\begin{array}{c}-0.015^{* *} \\
(0.007)\end{array}$ & $\begin{array}{c}-0.013 \\
(0.008)\end{array}$ & $\begin{array}{c}-0.015^{* *} \\
(0.007)\end{array}$ & $\begin{array}{c}-0.014^{* *} \\
(0.007)\end{array}$ & $\begin{array}{c}-0.014^{* *} \\
(0.007)\end{array}$ \\
\hline Manager tenure $_{t-1}$ & $\begin{array}{l}0.029^{* *} \\
(0.013)\end{array}$ & $\begin{array}{c}0.028^{* *} \\
(0.013)\end{array}$ & $\begin{array}{c}0.028^{* *} \\
(0.013)\end{array}$ & $\begin{array}{l}0.027^{* *} \\
(0.013)\end{array}$ & $\begin{array}{c}0.025^{*} \\
(0.013)\end{array}$ & $\begin{array}{c}0.027^{* *} \\
(0.013)\end{array}$ \\
\hline Fund age $_{t-1}$ & $\begin{array}{c}0.007 \\
(0.036)\end{array}$ & $\begin{array}{c}0.006 \\
(0.036)\end{array}$ & $\begin{array}{c}0.006 \\
(0.036)\end{array}$ & $\begin{array}{c}0.006 \\
(0.036)\end{array}$ & $\begin{array}{c}0.008 \\
(0.037)\end{array}$ & $\begin{array}{c}0.006 \\
(0.036)\end{array}$ \\
\hline Fund alpha $a_{t-1}$ & $\begin{array}{l}0.024^{* * *} \\
(0.004)\end{array}$ & $\begin{array}{l}0.024^{* * *} \\
(0.004)\end{array}$ & $\begin{array}{l}0.024^{* * *} \\
(0.004)\end{array}$ & $\begin{array}{l}0.024^{* * *} \\
(0.004)\end{array}$ & $\begin{array}{l}0.024^{* * *} \\
(0.004)\end{array}$ & $\begin{array}{l}0.024^{* * *} \\
(0.004)\end{array}$ \\
\hline Fund size $_{t-1}$ & $\begin{array}{c}-0.171^{* * *} \\
(0.012)\end{array}$ & $\begin{array}{c}-0.170^{* * *} \\
(0.012)\end{array}$ & $\begin{array}{c}-0.170^{* * *} \\
(0.012)\end{array}$ & $\begin{array}{c}-0.170^{* * *} \\
(0.012)\end{array}$ & $\begin{array}{c}-0.171^{* * *} \\
(0.012)\end{array}$ & $\begin{array}{c}-0.170^{* * *} \\
(0.012)\end{array}$ \\
\hline Fund expense $e_{t-1}$ & $\begin{array}{c}0.480 \\
(0.730)\end{array}$ & $\begin{array}{c}0.482 \\
(0.732)\end{array}$ & $\begin{array}{c}0.486 \\
(0.732)\end{array}$ & $\begin{array}{c}0.481 \\
(0.730)\end{array}$ & $\begin{array}{c}0.485 \\
(0.733)\end{array}$ & $\begin{array}{c}0.484 \\
(0.732)\end{array}$ \\
\hline Fund flow rate ${ }_{t-1}$ & $\begin{array}{l}0.002^{* *} \\
(0.001)\end{array}$ & $\begin{array}{c}0.002^{* *} \\
(0.001)\end{array}$ & $\begin{array}{l}0.002^{* *} \\
(0.001)\end{array}$ & $\begin{array}{c}0.002^{* *} \\
(0.001)\end{array}$ & $\begin{array}{l}0.002^{* *} \\
(0.001)\end{array}$ & $\begin{array}{c}0.002^{* *} \\
(0.001)\end{array}$ \\
\hline $\mathrm{N}$ & 268,537 & 268,537 & 268,537 & 268,537 & 268,537 & 268,537 \\
\hline $\operatorname{Adj} R^{2}$ & 0.12 & 0.13 & 0.13 & 0.13 & 0.13 & 0.13 \\
\hline Time FE & Yes & Yes & Yes & Yes & Yes & Yes \\
\hline Fund FE & Yes & Yes & Yes & Yes & Yes & Yes \\
\hline
\end{tabular}

The results from column (1) in Table 3.1 show that the connection duration between managers and all directors of the fund is significantly negative related to fund performance. 
For median funds, each additional 1-year connection between managers and directors lowers fund net abnormal returns by about $0.06 \%$ per year. When we split the connection into two parts: connection with independent directors and connection with inside directors, column (2) shows that only the connection duration with independent directors affects fund performance negatively.

Looking at other proxies for the quality of fund governance in column (1) and (2), funds with larger board size have significantly lower returns ${ }^{1}$, but the fraction of independent directors and the fraction of the fund owned by institutional investors (external control channel) are not related to fund performance. In addition, since directors sit on multiple fund boards, some directors on average monitor 45 funds while other directors may oversee as few as one fund. Hence, one may think that the number of funds directors manage will reduce their ability to monitor and govern properly, leading to a decline in fund performance. However, the results show that there is no relationship between fund performance and number of funds overseen by directors. It could be that firms with cluster boards may have designated committees who will interact closely with the investment teams of all funds that are managed by those directors, and then report back to directors ${ }^{2}$. Therefore, directors have an in-depth understanding of all funds they manage efficiently. These firms can also utilize other methods to reduce directors' work load, such as preparing reports with similar format or content across funds, etc.

\footnotetext{
${ }^{1}$ Guercio et al. (2003) and Adams et al. (2010) found similar results for closed-end funds and index funds, respectively.

${ }^{2}$ More details on investment performance oversight by fund boards can be found at https://www.idc. org/.
} 
One may expect that the negative relationship between fund performance and connection duration between managers and independent directors is lower for funds managed by a team of managers. To test this hypothesis, I add the interaction term of variables $\ln ($ Connection_IND+1) and Team size, the number of managers co-managing the fund, into Equation 3.1. Column (3) shows that the negative relationship is the same whether the fund is managed by an individual manager or by a team. Furthermore, I also interact $\ln ($ Connection_IND +1$)$ with a SubAdvisor dummy, that equals 1 if funds are outsourced, to examine whether this negative relationship exists in funds managed by the outside advisory firms. Since outside advisors and fund sponsors are two different firms, the connection between board directors and managers is expected to be not as tight as the connection between those employed in funds managed in-house. However, the results from column (4) surprisingly show that the negative relationship exists not only in funds managed in-house but also in outsourced funds. Lastly, to examine whether the effect of connection duration is sensitive to fund governance, I also interact $\ln ($ Connection_IND +1$)$ with Board size and Fraction institutional ownership. Column (5) and (6) show that the connection duration is negatively related to fund performance regardless of the percentage of institutional ownerships or board size. 


\section{Chapter 4}

\section{Manager survivorship in relation to their connec- tion with fund independent directors}

In this section, I study whether manager survivorship is related to the duration of his/her connection with the fund's independent directors and dependent directors. If board directors carry out their fiduciary duty properly, managers should be evaluated solely by their performance and not by their connection with the board. Inside directors and fund managers are perceived as the same team since these directors have a close relationship with the fund's adviser. Hence, their connection duration may not add any extra power in the manager survivorship at the funds. However, independent directors who have a longer connection with fund managers may give managers more time at the funds when these funds have bad performance.

Hypothesis 2 Connection duration between fund managers and fund independent (inside) directors is negatively (not) related to manager's hazard of turn over.

The Cox proportional hazard model is used to predict the hazard of manager turnover 
in the next month by using fund and manager characteristics:

$$
\begin{aligned}
\lambda(t)=\lambda_{0}(t) \exp [ & \beta_{1} \ln \left(\text { Connection_IN } D_{m i, t-1}+1\right) \\
& +\beta_{2} \ln \left(\text { Connection_DE } P_{m i, t-1}+1\right) \\
& \left.+\gamma_{1} \text { Manager Char }{ }_{m, t-1}+\gamma_{2} \text { Fund Char } r_{i, t-1}\right]
\end{aligned}
$$

where Connection_IND $D_{m i, t-1}$ and Connection_DEP $P_{m i, t-1}$ are number of years manager $m$ has been connected to fund $i$ 's independent and dependent directors up to time $t-1$ that are defined in Equation 2.2. Manager Char $_{m, t-1}$ includes control variables for manager characteristics: gender (Female dummy), SAT score divided by 100 (SAT), whether managers hold CFA certificate ( $C F A$ dummy), whether managers have master or/and $\mathrm{PhD}$ degree (Master dummy). Fund Char ${ }_{m, t-1}$ consists of fund characteristics: the ratio of number of independent directors to board size (Frac. ind. director); the number of directors sitting on the board (Board size), the fraction of the fund owned by institutional investors (Fraction Institutional ownership), the number of managers who co-manage the fund (Team size), whether funds are outsourced (SubAdvisor dummy), logarithm of total fund net assets (Fund size), fund total expense ratio (Fund expense), fund average net abnormal returns for the past 36 months (Fund alpha $a_{[t-36, t-1]}$ ). The sample includes only managers who manage funds more than three years to correctly measure the manager's contribution to the fund's past three-year performance. In addition, the model takes into account that sample data is right censored since not all managers experience turnover during 
my sample periods. Manager turnover is defined as when managers leave the fund and the fund survives after these departures.

The model also adds the interaction between $C F A$ dummy, SAT, Frac. ind. director, Board size, and Team size with manager tenure, which is the logarithm of manager tenure within a fund plus one. Only these variables have the interactions because they do not satisfy the proportional hazards assumption, which is that survival curves for two values of the same variables must have hazard functions that are proportional over time. Table 4.1 presents the estimated coefficients from the Cox model and the $p$-value of the Schoenfeld residual test, which is the proportional hazards assumption test. Column (1) shows that the coefficients of these interactions are all significant different than zero, which means that by adding these terms into the model, they will correct for the non-proportional hazards for the

\section{Table 4.1}

Cox proportional hazard model of turnover.

This table reports results for Cox proportional hazard regression of manager turnover. The data are right censored because not all managers leave funds in the sample. Sample includes only managers who manage the fund more than a year. $I N D(D E P)$ is logarithm of one plus connection duration (in years) between managers and independent (dependent) directors of the fund. Man. tenure is logarithm of manager tenure within a fund (in years) plus one. Female dummy is equal 1 if managers are female. SAT is average admission SAT score of the undergraduate institution of the manager divided by 100. CFA dummy is equal to 1 if managers hold CFA certificate. Master dummy is equal to 1 if managers have master or/and $\mathrm{PhD}$ degree. Frac. ind. director is the ratio of number of independent directors to board size. Board size is the number of board directors work for a fund. Institutional ownership is the fraction of fund owned by institutional investors. Team size is the number of managers who co-manage the fund. SubAdvisor dummy is equal to 1 if the fund is outsourced. Fund size is logarithm of total fund net assets. Fund expense is fund total expense ratio. Fund alpha $a_{[-36, t-1]}$ is fund's average net abnormal returns for periods $[t-36, t-1]$. Standard errors clustered at the family level are in parentheses and ${ }^{*},{ }^{* *},{ }^{* *}$ indicate significance at the $10 \%, 5 \%$, and $1 \%$ levels respectively. 
Table 4.1 (continued)

\begin{tabular}{|c|c|c|c|c|c|}
\hline & \multicolumn{4}{|c|}{ Cox propotional hazard estimates } & \multirow{2}{*}{$\begin{array}{c}p \text {-value of } \\
\text { Schoenfeld } \\
\text { test }\end{array}$} \\
\hline & (1) & (2) & (3) & (4) & \\
\hline $\mathrm{IND}_{t-1}$ & $\begin{array}{c}-0.307^{* *} \\
(0.131)\end{array}$ & $\begin{array}{l}-0.956^{* * *} \\
(0.219)\end{array}$ & $\begin{array}{l}-0.518^{* * *} \\
(0.118)\end{array}$ & $\begin{array}{l}-0.365^{* * *} \\
(0.097)\end{array}$ & 0.264 \\
\hline $\mathrm{DEP}_{t-1}$ & $\begin{array}{r}-0.120 \\
(0.137)\end{array}$ & & & & 0.004 \\
\hline $\mathrm{IND}_{t-1} \times$ Team size $_{t-1}$ & & $\begin{array}{l}0.141^{* *} \\
(0.057)\end{array}$ & & & \\
\hline $\mathrm{IND}_{t-1} \times$ Inst. ownership $p_{t-1}$ & & & $\begin{array}{r}0.423^{*} \\
(0.243)\end{array}$ & & \\
\hline $\mathrm{IND}_{t-1} \times \mathrm{Fund}_{\text {alpha }}[t-36, t-1]$ & & & & $\begin{array}{l}0.267^{* *} \\
(0.128)\end{array}$ & \\
\hline Fund alpha $[t-36, t-1]$ & $\begin{array}{l}-0.383^{* * *} \\
(0.055)\end{array}$ & $\begin{array}{l}-0.373^{* * *} \\
(0.056)\end{array}$ & $\begin{array}{l}-0.384^{* * *} \\
(0.056)\end{array}$ & $\begin{array}{l}-0.457^{* * *} \\
(0.072)\end{array}$ & 0.860 \\
\hline Female dummy & $\begin{array}{l}0.185^{* * *} \\
(0.054)\end{array}$ & $\begin{array}{l}0.175^{* * *} \\
(0.052)\end{array}$ & $\begin{array}{l}0.189^{* * *} \\
(0.054)\end{array}$ & $\begin{array}{l}0.189^{* * *} \\
(0.053)\end{array}$ & 0.391 \\
\hline Master dummy $_{t-1}$ & $\begin{array}{c}0.023 \\
(0.042)\end{array}$ & $\begin{array}{c}0.021 \\
(0.042)\end{array}$ & $\begin{array}{c}0.022 \\
(0.042)\end{array}$ & $\begin{array}{c}0.024 \\
(0.042)\end{array}$ & 0.732 \\
\hline CFA dummy $_{t-1}$ & $\begin{array}{l}-0.481^{* * *} \\
(0.158)\end{array}$ & $\begin{array}{l}-0.449^{* * *} \\
(0.158)\end{array}$ & $\begin{array}{l}-0.482^{* * *} \\
(0.158)\end{array}$ & $\begin{array}{l}-0.479^{* * *} \\
(0.158)\end{array}$ & 0.065 \\
\hline CFA dummy $_{t-1} \times$ Man. tenure $_{t-1}$ & $\begin{array}{l}0.256^{* * *} \\
(0.094)\end{array}$ & $\begin{array}{l}0.235^{* *} \\
(0.094)\end{array}$ & $\begin{array}{l}0.257^{* * *} \\
(0.094)\end{array}$ & $\begin{array}{l}0.255^{* * *} \\
(0.094)\end{array}$ & 0.050 \\
\hline SAT & $\begin{array}{r}-0.096^{*} \\
(0.053)\end{array}$ & $\begin{array}{l}-0.104^{* *} \\
(0.053)\end{array}$ & $\begin{array}{r}-0.094^{*} \\
(0.053)\end{array}$ & $\begin{array}{r}-0.095^{*} \\
(0.053)\end{array}$ & 0.261 \\
\hline $\mathrm{SAT} \times$ Man. tenure ${ }_{t-1}$ & $\begin{array}{l}0.071^{* *} \\
(0.031)\end{array}$ & $\begin{array}{l}0.074^{* *} \\
(0.031)\end{array}$ & $\begin{array}{l}0.069^{* *} \\
(0.031)\end{array}$ & $\begin{array}{l}0.071^{* *} \\
(0.031)\end{array}$ & 0.217 \\
\hline Frac. ind. director ${ }_{t-1}$ & $\begin{array}{l}2.489^{* * *} \\
(0.833)\end{array}$ & $\begin{array}{l}2.562^{* * *} \\
(0.832)\end{array}$ & $\begin{array}{l}2.464^{* * *} \\
(0.838)\end{array}$ & $\begin{array}{l}2.411^{* * *} \\
(0.840)\end{array}$ & 0.174 \\
\hline Frac. ind. director ${ }_{t-1} \times$ Man. tenure $e_{t-1}$ & $\begin{array}{c}-1.186^{* *} \\
(0.487)\end{array}$ & $\begin{array}{l}-1.168^{* *} \\
(0.479)\end{array}$ & $\begin{array}{c}-1.144^{* *} \\
(0.482)\end{array}$ & $\begin{array}{c}-1.089^{* *} \\
(0.483)\end{array}$ & 0.316 \\
\hline Board size $e_{t-1}$ & $\begin{array}{l}0.068^{* *} \\
(0.032)\end{array}$ & $\begin{array}{l}0.074^{* *} \\
(0.032)\end{array}$ & $\begin{array}{l}0.069^{* *} \\
(0.032)\end{array}$ & $\begin{array}{l}0.069^{* *} \\
(0.032)\end{array}$ & 0.575 \\
\hline Board size $_{t-1} \times$ Man. tenure t $_{t-1}$ & $\begin{array}{r}-0.032^{*} \\
(0.019)\end{array}$ & $\begin{array}{c}-0.037^{* *} \\
(0.018)\end{array}$ & $\begin{array}{r}-0.033^{*} \\
(0.019)\end{array}$ & $\begin{array}{r}-0.032^{*} \\
(0.019)\end{array}$ & 0.585 \\
\hline Fraction institutional ownership t $_{t-1}$ & $\begin{array}{c}-0.194^{* *} \\
(0.079)\end{array}$ & $\begin{array}{l}-0.202^{* * *} \\
(0.075)\end{array}$ & $\begin{array}{l}-0.289^{* * *} \\
(0.107)\end{array}$ & $\begin{array}{c}-0.193^{* *} \\
(0.079)\end{array}$ & 0.158 \\
\hline SubAdvisor dummy & $\begin{array}{r}-0.030 \\
(0.048)\end{array}$ & $\begin{array}{r}-0.039 \\
(0.048)\end{array}$ & $\begin{array}{r}-0.024 \\
(0.048)\end{array}$ & $\begin{array}{r}-0.029 \\
(0.048)\end{array}$ & 0.239 \\
\hline Team size $t-1$ & $\begin{array}{l}0.069^{* * *} \\
(0.012)\end{array}$ & $\begin{array}{l}0.079^{* * *} \\
(0.012)\end{array}$ & $\begin{array}{l}0.070^{* * *} \\
(0.012)\end{array}$ & $\begin{array}{l}0.068^{* * *} \\
(0.012)\end{array}$ & 0.255 \\
\hline Team size $_{t-1} \times$ Man. tenure $_{t-1}$ & $\begin{array}{r}-0.012^{*} \\
(0.007)\end{array}$ & $\begin{array}{l}-0.031^{* * *} \\
(0.009)\end{array}$ & $\begin{array}{r}-0.013^{*} \\
(0.007)\end{array}$ & $\begin{array}{r}-0.012^{*} \\
(0.007)\end{array}$ & 0.550 \\
\hline Fund size ${ }_{t-1}$ & $\begin{array}{l}-0.085^{* * *} \\
(0.014)\end{array}$ & $\begin{array}{l}-0.087^{* * *} \\
(0.014)\end{array}$ & $\begin{array}{l}-0.086^{* * *} \\
(0.014)\end{array}$ & $\begin{array}{l}-0.085^{* * *} \\
(0.014)\end{array}$ & 0.695 \\
\hline $\mathrm{N}$ & 322,433 & 322,433 & 322,433 & 322,433 & \\
\hline Hazards model assumption global test & & & & & 0.263 \\
\hline
\end{tabular}


main variables. In addition, the last column in Table 4.1 shows that except for Connection_DEP variable, the Schoenfeld residual tests are not statistically significant for all other variables, and the global test is also not statistically significant. These results indicate an absence of evidence to contradict the proportionality assumption.

To interpret the results of Cox proportional hazard, the hazard of turnover when there is a $\delta$ change in the control variable $x$ is $e^{\delta \beta^{x}}$, where $\beta^{x}$ is the coefficient on $x$. Column (1) confirms that managers are evaluated by their performance. The higher the funds perform in the last 36 months, the lower the risk of turn over managers face. Furthermore, the hazard of turnover is also significantly lower when managers have a longer connection duration with the fund's independent directors, but it does not have any relation to the connection duration with inside directors. Specifically, compared to managers with a 1-year connection with directors, those with 5 -year connection have a $29 \%$ lower hazard rate. Female managers have about a $20 \%$ higher hazard rate compare to male managers. Funds owned more by institutional investors also have lower manager turnover. Only managers who have less than 5-year tenure benefit from holding a CFA certificate. In addition, those with less than 5-year tenure will have a higher hazard rate within funds with a higher fraction of independent directors. For those with more than a 5-year tenure, the fund's fraction of independent directors does not affect manager turnover. Using results from column (1) with all predictors at their mean value, Figure 4.1 illustrates the survivor probability for managers who have 1-year versus 5 -year connection with fund independent directors. Those with 5-year connection have on average $10 \%$ higher survivor probability. 


\section{Figure 4.1}

Manager survivorship.

This figure shows the survival probability for managers using the results from column (1) in Table 4.1 , and all other predictors at their mean value.

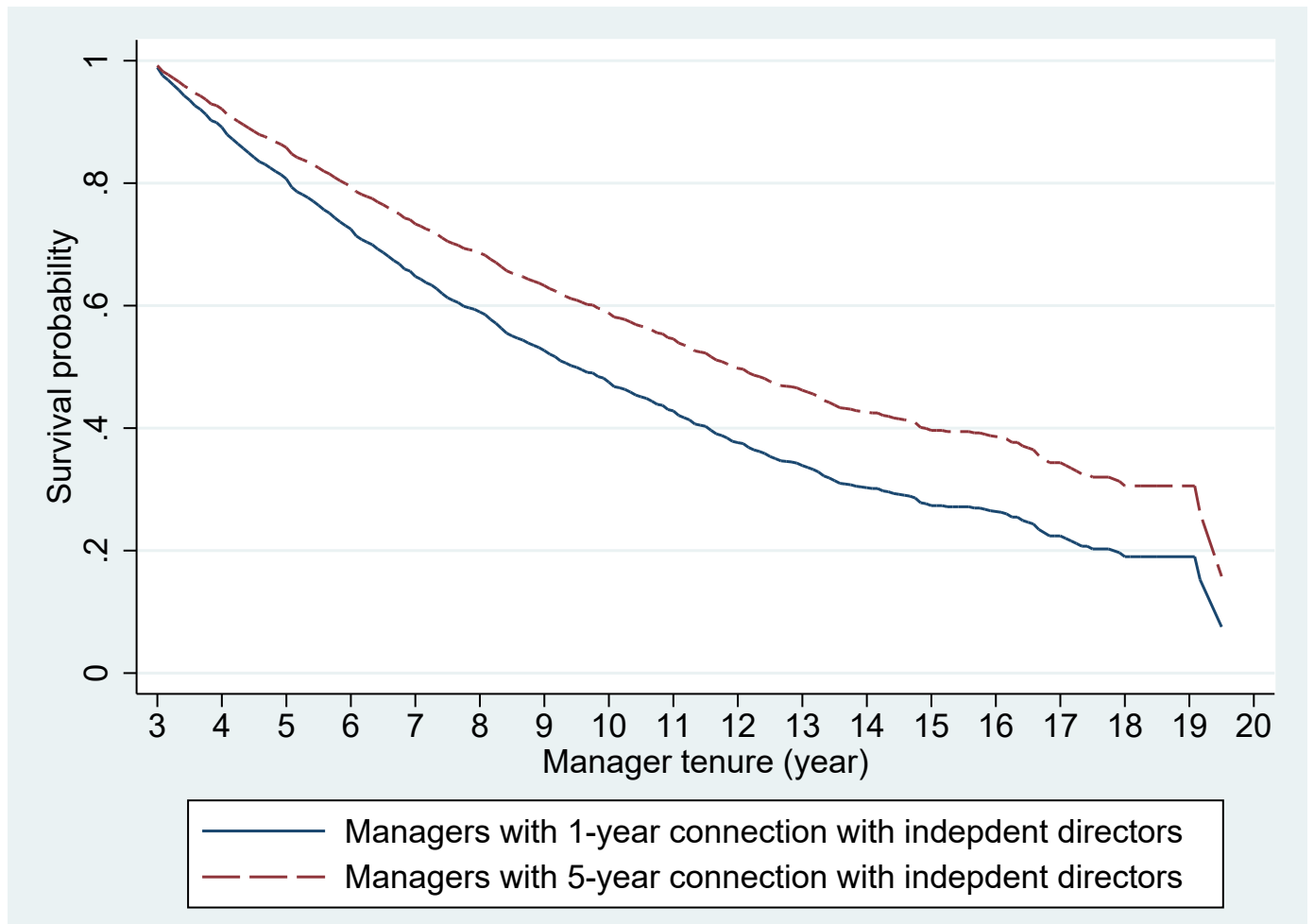

To examine whether the effect of director-manager connection on manager survivorship is the same at different fund characteristics, I interact the connection variable with Team size, Fraction Institutional ownership, and Fundalpha $a_{[t-36, t-1]}$. Column (2) reports the results when I add the interaction with Team size. Managers who work in a team of less than four members have significant benefits from the connection with independent directors. Those who manage the fund alone have the most benefit. Figure 4.2 (a) shows that the effect of the director-manager connection on manager survivorship decreases with team size. 


\section{Figure 4.2}

Cox hazard model: Sensitivity of Connection Duration on key variables.

Figures (a), (b), and (c) present the value of $\beta_{1}+\beta_{2} X_{i, t-1}$, where control variables $X_{i, t-1}=$ $\left\{\right.$ Team size, Fraction institutional ownership, Fund alpha ${ }_{[t-36, t-1]}$ (fund average past 36month net alpha)\} from columns (2)-(4) in Table 4.1 estimated using Cox proportional hazard regression of manager turnover:

$$
\begin{aligned}
\lambda(t)=\lambda_{0}(t) \exp \left[\left(\beta_{1}+\beta_{2} X_{i, t-1}\right)\right. & \ln \left(\text { Connection_IND }_{m i, t-1}+1\right)+\beta_{3} \text { Fund alpha }_{[t-36, t-1]} \\
& \left.+\gamma_{1} \text { Manager Char } \text { Ch,t-1 }_{\text {Mand }}+\gamma_{2} \text { Fund Char }_{i, t-1}\right]
\end{aligned}
$$

Figure (d) presents the total value of coefficients on Fund alpha $a_{[t-36, t-1]}$, which is $\beta_{3}+$ $\beta_{2} \ln \left(\right.$ Connection_IN $\left.D_{m i, t-1}+1\right)$, from column (4) in Table 4.1.

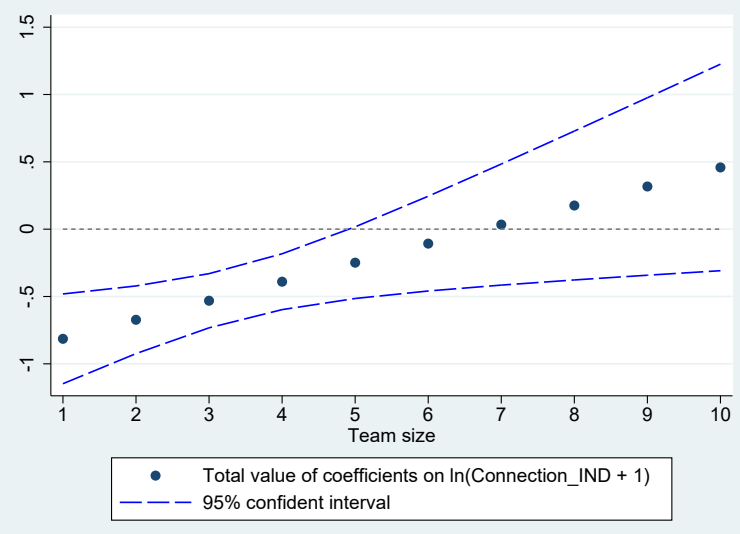

(a) $\beta_{1}+\beta_{2}$ Team size.

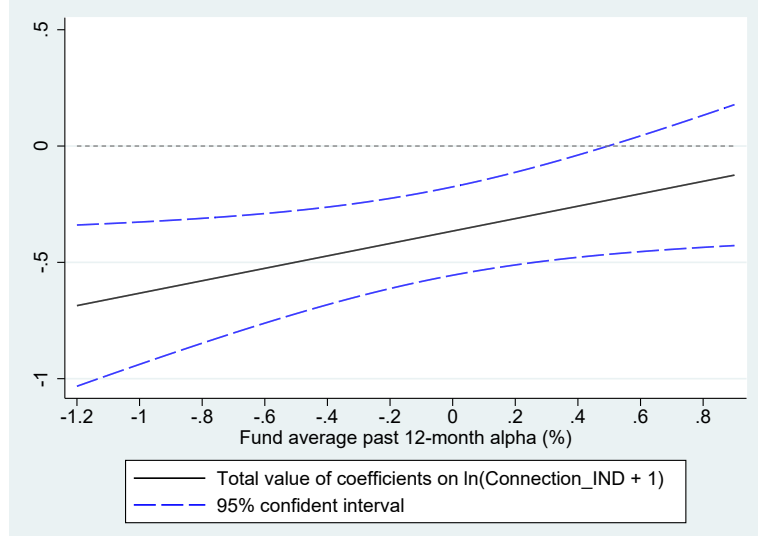

(c) $\beta_{1}+\beta_{2}$ Fund alpha $[t-36, t-1]$.

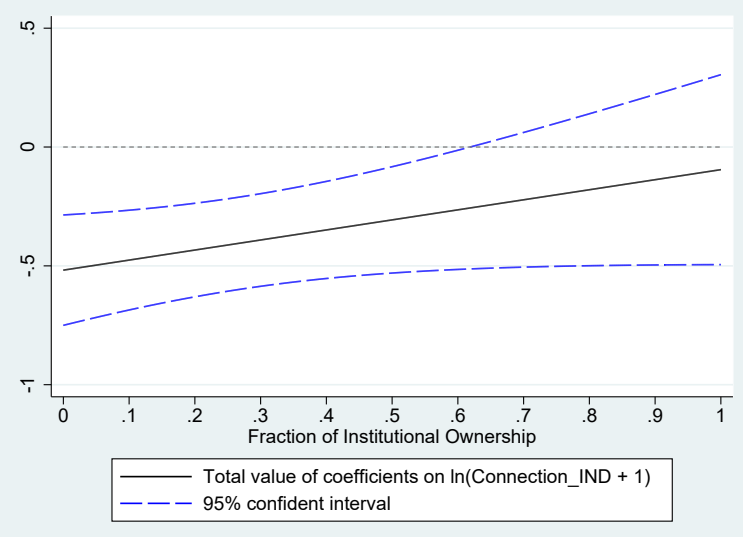

(b) $\beta_{1}+\beta_{2}$ Fraction inst. owner ship.

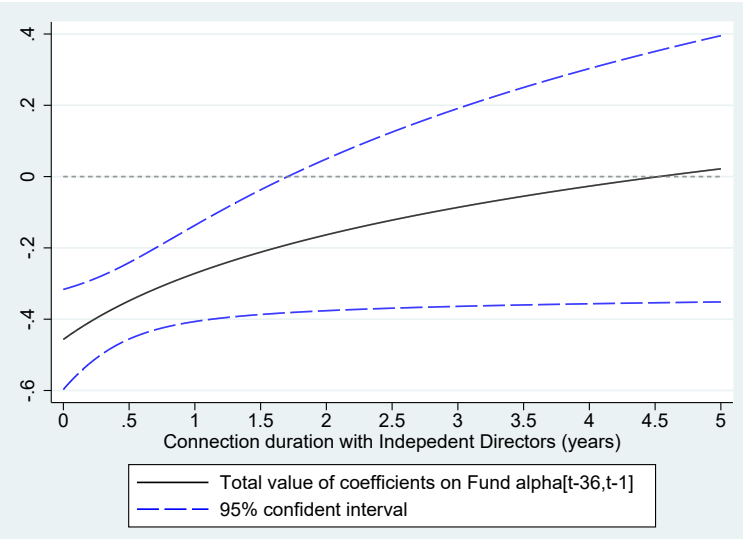

(d) $\beta_{3}+\beta_{2} \ln \left(\right.$ Connection_IND $\left.D_{m i, t-1}+1\right)$. 
Column (3) adds the interaction of the director-manager connection with the fraction of funds owned by institutional investors to test for the sensitivity of connection duration on manager turnover. The results show that the connection effect is significantly smaller when funds are owned more by institutional investors. Figure 4.2 (b) exhibits the declining effect. Furthermore, this effect is only significant when these professional investors owned less than $60 \%$ of the fund assets.

Column (4) adds the interaction with past three-year performance. Figure 4.2 (c) shows that the connection effect significantly decreases in fund performance. Managers with good past performance do not need a connection to stay longer. However, those with poor performance need these connections the most. This result suggests that there is a large fraction of underperforming managers who are less likely to be terminated just because they have a long-term connection with fund's independent directors.

Lastly, Figure 4.2 (d) displays the sensitivity of the past performance on hazard of turnover to the connection duration. It shows that the performance of managers who have more than one and a half-year experience with independent directors does not affect managers' hazard of turn over. Since the connection duration is scaled by the number of funds that independent directors oversee, this one and a half years is at 96 percentiles of the connection duration distribution. Consequently, only those with a significant relationship with independent directors have no risk from poor performance.

In sum, the evidence that the effect of independent director-manager connection duration on manager turnover significantly decreases in team size, decreases in fund governance 
quality, and is persistent even when funds have negative performance indicates that there is manager entrenchment in the mutual fund industry. 


\section{Chapter 5}

\section{Hiring managers who have a tight connection with fund directors}

Previous results suggest that the long-term connection between managers and independent directors harms investors while managers are working at the fund. However, initially it could be that, in an ex-ante hiring decision, directors want to bring in talented managers with whom they have extended working relationships for the benefit of investors. On the other hand, bringing in well-connected managers would gain private benefit for both of them at the expense of investors.

Hypothesis 3.A Hiring well-connected managers will decrease fund performance. Hypothesis 3.B Hiring well-connected managers will increase fund performance.

This subsection is devoted to examining the cost/benefit of hiring well-connected managers. I consider two levels of well-connectedness: [1] the first level is for newly hired managers who have a long-term connection, as defined in Equation 2.2, with directors of hiring funds, and [2] the next level is for managers with long-term connection and a tight form of connection with directors. Newly hired managers are said to have a tight connection with directors of hiring funds if [1] manager and director are/were co-managers at 
other funds (called Hiring-Teammate managers, hereafter), or [2] managers are rehired by the funds where they worked before (Boomerang managers) and fund directors sit on the board in both terms of these managers. Figure 5.1 illustrates the definition of these types of managers. The focus of this section is to study the cost/benefit of hiring Hiring-Teammate and Boomerang managers.

\section{Figure 5.1}

Time line when funds hire Hiring-Teammate and Boomerang managers.

This figure presents the time line of funds that hire Hiring-Teammate and Boomerang managers. Fund X hires manager Hiring-Teammate $M$ at period $t_{h}$ when director $D$ sits on fund X's board. Both Hiring-Teammate $M$ and $D$ are managers of fund $\mathrm{Y}$ before Hiring-Teammate $M$ joins fund $\mathrm{X}$. Fund $\mathrm{Z}$ rehires manager Boomerang $A$ at period $t_{b}$. This manager worked at fund $\mathrm{Z}$, left for at least siz months, then come back at period $t_{b}$.

$\underline{\text { Hiring-Teammate managers: }}$

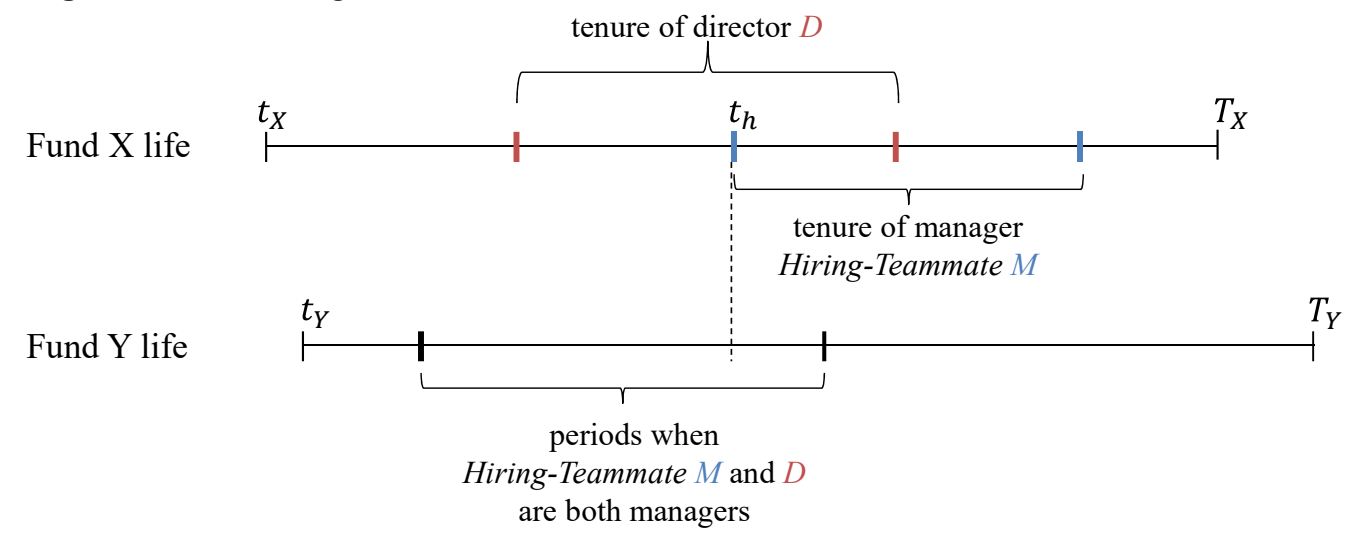

Boomerang managers:

Fund $\mathrm{Z}$ life

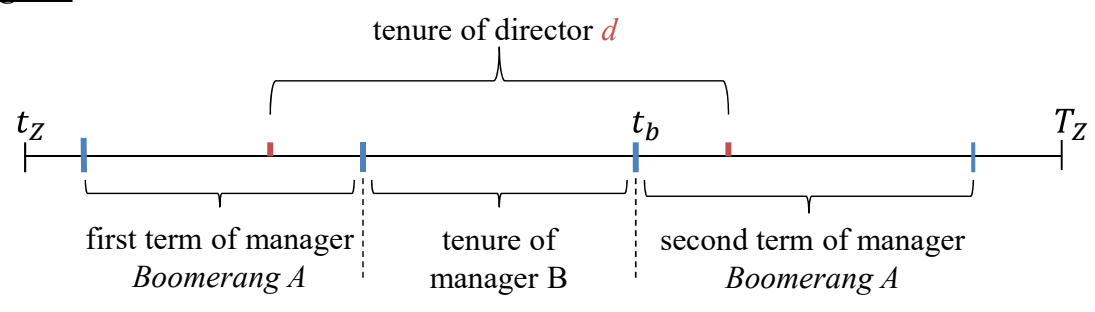




\subsection{Sample selections and summary statistics}

The sample includes 2,046 funds that hire 2,300 managers, who first appear in both CRSP and Morningstar databases since 1996. To examine a fund's 2-year performance before and after hiring, I require that these hires take place at least 18 months after the fund's inception date, and newly hired managers need to work there for at least 18 months. Fund monthly net abnormal returns are estimated using data from two non-overlapping periods: 3 years before hiring and the minimum of 3 years after hiring and the tenure of newly hired managers at hiring funds. The sample are split into three sub-samples: [1] Hiring-Teammate sample includes fund-manager observations where managers and fund directors are/were co-managers at other funds; [2] Boomerang sample consists of funds that rehire managers who previously worked at these funds. Additionally, they needed to have worked at these funds for at least a year in the first employment and have left the funds for at least six months; [3] control samples includes any other new hires that are classified as either internal or external hires (managers are internally hired when they are currently working at other fund(s) in the same family). 


\section{Table 5.1}

Summary statistics for funds and managers before new hires.

This table reports summary statistics, average[median/standard deviation], for major variables at month $t$ when funds hire new managers at the middle of fund life. Hiring-Teammate sample includes funds whose new hired managers and their directors are/were co-managers at other funds. Boomerang sample includes funds that rehire managers who used to work at these funds. Control sample includes any new hires that are classified as either internal or external hires. Managers are internally hired when these managers are currently working at other fund(s) in the same family. The difference in mean tests between control sample and Hiring-Teammate (Boomerang) sample are represented by ${ }^{t}$ and ${ }^{t t}\left({ }^{b}\right.$ and $\left.{ }^{b b}\right)$, indicating significance at the 5\% and $1 \%$ levels respectively. Independent directors are those who do not have any significant relationship with the fund's adviser or underwriter. Fraction ind. directors is the ratio of the number of independent board directors to board size. Frac. ins. ownership $[t-24, t-1]$ is the average fraction of funds owned by institutional investors for periods $[t-24, t-1]$. Board size is the number of directors who work at the fund. Fund size $[t-24, t-1]$ is the average total net assets for periods $[t-24, t-1]$. Fund expense $[t-24, t-1]$ is the average expense ratio for periods $[t-24, t-1]$. Tenure is manager tenure since he/she first appears in the database. Female dummy is equal to 1 if managers are female. Master degree dummy is equal to 1 if managers have master degree. CFA dummy is equal to 1 if managers hold CFA certificate.

\begin{tabular}{|c|c|c|c|c|}
\hline \multirow[b]{2}{*}{ Variables } & \multirow[b]{2}{*}{ Hiring-Teammate } & \multirow[b]{2}{*}{ Boomerang } & \multicolumn{2}{|c|}{ Control sample } \\
\hline & & & Internal hires & External hires \\
\hline \multicolumn{5}{|c|}{ Percentage of directors who had a director-manager relationship with new hired managers before hiring: } \\
\hline $\begin{array}{l}\text { - Independent directors } \\
\text { - Inside directors } \\
\text { - All directors }\end{array}$ & $\begin{array}{l}82.0[100.0 / 33.4] \\
76.2[100.0 / 39.4] \\
82.6[100.0 / 32.1]\end{array}$ & $\begin{array}{l}87.4[100.0 / 24.5] \\
73.5[100.0 / 41.8] \\
86.5[100.0 / 24.8]\end{array}$ & $\begin{array}{l}77.4[100.0 / 38.5]^{t, b b} \\
69.3[100.0 / 44.6]^{t} \\
77.5[100.0 / 38.0]^{t, b b}\end{array}$ & $\begin{array}{l}5.2[0.0 / 19.0]^{t t, b b} \\
5.3[0.0 / 19.9]^{t t, b b} \\
5.3[0.0 / 19.0]^{t t, b b}\end{array}$ \\
\hline \multicolumn{5}{|c|}{ Connection duration (in months) of director and new hired managers before hiring: } \\
\hline $\begin{array}{l}\text { - Independent directors } \\
\text { - Inside directors } \\
\text { - All directors }\end{array}$ & $\begin{array}{l}4.0[1.9 / 5.9] \\
3.8[1.4 / 6.0] \\
4.1[1.8 / 6.0]\end{array}$ & $\begin{array}{l}4.1[1.9 / 6.0] \\
3.6[1.2 / 7.5] \\
4.2[1.8 / 6.2]\end{array}$ & $\begin{array}{l}1.3[0.6 / 2.8]^{t t, b b} \\
1.1[0.3 / 2.4]^{t t, b b} \\
1.3[0.6 / 2.6]^{t t, b b}\end{array}$ & $\begin{array}{l}0.1[0.0 / 0.4]^{t t, b b} \\
0.1[0.0 / 0.4]^{t t, b b} \\
0.1[0.0 / 0.4]^{t t, b b}\end{array}$ \\
\hline \multicolumn{5}{|c|}{ Number of funds directors had a director-manager relationship with new hired managers before hiring: } \\
\hline $\begin{array}{l}\text { - Independent directors } \\
\text { - Inside directors } \\
\text { - All directors }\end{array}$ & $\begin{array}{l}1.4[1.0 / 1.0] \\
1.5[1.0 / 1.4] \\
1.4[1.0 / 1.1]\end{array}$ & $\begin{array}{l}1.7[1.0 / 2.1] \\
1.7[1.0 / 2.8] \\
1.8[1.0 / 2.2]\end{array}$ & $\begin{array}{l}1.2[1.0 / 1.4]^{t t, b b} \\
1.1[1.0 / 1.6]^{t t, b b} \\
1.2[1.0 / 1.4]^{t t, b b}\end{array}$ & $\begin{array}{l}0.1[0.0 / 0.3]^{t t, b b} \\
0.1[0.0 / 0.3]^{t t, b b} \\
0.1[0.0 / 0.3]^{t t, b b}\end{array}$ \\
\hline Observations (fund $\times$ hiring month) & 250 & 347 & 1,970 & 1,610 \\
\hline
\end{tabular}


Table 5.1 (continued)

\begin{tabular}{|c|c|c|c|c|}
\hline \multirow[b]{2}{*}{ Variables } & \multirow[b]{2}{*}{ Hiring-Teammate } & \multirow[b]{2}{*}{ Boomerang } & \multicolumn{2}{|c|}{ Control sample } \\
\hline & & & Internal hires & External hires \\
\hline \multicolumn{5}{|l|}{ Fund characteristics: } \\
\hline Fraction ind. directors ${ }_{t-1}(\%)$ & $78.2[80.0 / 11.4]$ & $78.6[80.0 / 12.3]$ & $80.7[83.3 / 13.5]^{t t, b b}$ & $81.1[81.8 / 11.4]^{t t, b b}$ \\
\hline Frac. inst. ownership $[t-24, t-1](\%)$ & $13.9[0.0 / 29.9]$ & $17.2[0.0 / 31.1]$ & $23.4[1.7 / 35.3]^{t t, b b}$ & $26.6[2.1 / 37.5]^{t t, b b}$ \\
\hline Board size $_{t-1}$ & $7.2[8.0 / 2.1]$ & $8.1[8.0 / 2.9]$ & $9.2[9.0 / 2.8]^{t t, b b}$ & $8.3[8.0 / 2.5]^{t t}$ \\
\hline 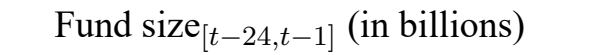 & $1.61[0.23 / 6.07]$ & $1.21[0.25 / 3.85]$ & $1.68[0.39 / 6.52]$ & $1.18[0.28 / 5.15]$ \\
\hline Fund expense $_{[t-24, t-1]}(\%)$ & $0.10[0.10 / 0.04]$ & $0.11[0.10 / 0.04]$ & $0.10[0.10 / 0.04]^{b b}$ & $0.10[0.10 / 0.04]$ \\
\hline Observations (fund $\times$ hiring_month) & 250 & 347 & 1,970 & 1,610 \\
\hline \multicolumn{5}{|l|}{ Manager characteristics: } \\
\hline Tenure $_{t-1}$ (in years) & $7.35[6.00 / 5.49]$ & $9.38[8.00 / 6.11]$ & $5.85[5.00 / 3.35]^{t t, b b}$ & $6.21[5.00 / 3.44]^{t t, b b}$ \\
\hline Female dummy & $0.08[0.00 / 0.28]$ & $0.06[0.00 / 0.25]$ & $0.10[0.00 / 0.30]^{b}$ & $0.09[0.00 / 0.29]$ \\
\hline Master degree dummy $_{t-1}$ & $0.67[1.00 / 0.47]$ & $0.70[1.00 / 0.46]$ & $0.68[1.00 / 0.47]$ & $0.71[1.00 / 0.45]$ \\
\hline $\mathrm{CFA}_{\text {dummy }}{ }_{t-1}$ & $0.58[1.00 / 0.49]$ & $0.52[1.00 / 0.50]$ & $0.56[1.00 / 0.50]$ & $0.61[1.00 / 0.49]^{b b}$ \\
\hline Obs. (manager $\times$ hiring_month) & 189 & 292 & 1,881 & 1,815 \\
\hline
\end{tabular}


Table 5.1 reports summary statistics for the final sample. Compared to internal and external hires, Hiring-Teammate and Boomerang managers have extended prior connections with fund directors before joining the funds. The connection here is in the form of the director-manager relationship. For instance, the percentage of independent directors and inside directors having connections with Hiring-Teammate (Boomerang) managers are $82 \%(87 \%)$ and $76 \%(74 \%)$ and they are significantly higher than those in the internal hires (77\% and 69\%) and external hires (5\% and 5\%) samples. Hiring-Teammate and Boomerang managers also have significantly longer connection duration with both independent and insider directors, and manage significantly more funds with them. In addition, funds that hire Hiring-Teammate and Boomerang managers have a significantly lower fraction of independent directors and fraction of institutional ownership than those hiring internal and external hires. They also have significantly smaller board size, but fund size and fund expense are similar. For managers, Hiring-Teammate and Boomerang managers have significantly longer tenures than those in the control sample. However, other characteristics, such as gender, CFA holder, and master degree holder are pretty much the same with those in the control sample.

In sum, funds that hire Hiring-Teammate and Boomerang managers have weak governance and these managers have significant connection with these fund directors before hiring. 


\subsection{Fund performance when hiring connected versus non- connected managers}

First, I examine the difference in two-year performance between funds hiring managers who have a prior director-manager relationship with the fund's independent directors (connected managers) and those hiring managers who do not have any prior connection (nonconnected managers). The full sample is split into three bins based on director-manager connection durations, as defined in Equation 2.2: [1] the first bin includes only funds hiring non-connected managers, [2] those hiring connected managers are assigned to bins 2 and 3 based on connection duration. Table 5.2 illustrates that the average prior connection duration is 0.42 and 4.01 years for bin 2 and bin 3 . The average two-year performance before and after hiring managers who have a long connection duration is no different than those hiring managers without any connection. Additionally, there is no performance improvement after hiring these managers. Therefore, hiring connected managers is not a determinant of fund performance. 


\section{Table 5.2}

Fund performance when hiring connected versus non-connected managers.

This table reports fund's average net abnormal return (in percentages) two years before and after managers join the funds. The sample are split into 3 bins based on director-manager connection durations before the time managers join the funds. Bin 1 includes only new hired managers who do not have any prior connection with independent directors. Connection duration is an average of directormanager connection duration before hiring within each bin. Standard errors are in parentheses and ${ }^{*},{ }^{* *},{ }^{* * *}$ indicate significance at the $10 \%, 5 \%$, and $1 \%$ levels respectively.

\begin{tabular}{|c|c|c|c|c|c|}
\hline Group & Number of hires & $\begin{array}{c}\text { Connection duration } \\
\text { (years) }\end{array}$ & $\begin{array}{l}\text { Before hiring } \\
\text { (1) }\end{array}$ & $\begin{array}{l}\text { After hiring } \\
\text { (2) }\end{array}$ & $\begin{array}{l}\text { Difference } \\
\text { (2) - (1) }\end{array}$ \\
\hline 1 & 1,794 & 0 & $\begin{array}{l}-0.125^{* * *} \\
(0.012)\end{array}$ & $\begin{array}{l}-0.126^{* * *} \\
(0.011)\end{array}$ & $\begin{array}{l}-0.001 \\
(0.015)\end{array}$ \\
\hline 2 & 1,199 & 0.42 & $\begin{array}{l}-0.112^{* * *} \\
(0.018)\end{array}$ & $\begin{array}{l}-0.083^{* * *} \\
(0.014)\end{array}$ & $\begin{array}{c}0.029 \\
(0.022)\end{array}$ \\
\hline 3 & 1,184 & 4.01 & $\begin{array}{l}-0.131^{* * *} \\
(0.015)\end{array}$ & $\begin{array}{l}-0.151^{* * *} \\
(0.015)\end{array}$ & $\begin{array}{l}-0.020 \\
(0.020)\end{array}$ \\
\hline $3-1$ & & & $\begin{array}{l}-0.006 \\
(0.020)\end{array}$ & $\begin{array}{l}-0.025 \\
(0.018)\end{array}$ & $\begin{array}{l}-0.019 \\
(0.025)\end{array}$ \\
\hline
\end{tabular}

\subsection{Fund performance when hiring Hiring-Teammate man- agers}

Table 5.3 shows that a fund's average monthly net alpha within the first two years employment of Hiring-Teammate managers is $-0.19 \%$ and it is significantly lower than that of funds in the control group, with the value of $-0.08 \%$. In addition, the change in average two-year performance before and after hiring is also lower by $0.09 \%$ but only at the $10 \%$ significant level. These results are the same if we compare the performance of funds managed by Hiring-Teammate managers to that of funds managed by either internal-hired or external-hired managers. 


\section{Table 5.3}

Fund performance when hiring managers who were/are co-managers with fund's directors at other funds.

This table reports fund's average net abnormal return (in percentages) two years before and after managers join the funds. $t$ is the first month of managers' tenure at the new funds. Control sample is also split into two subsamples that include only managers who are either internally or externally hired. Managers are internally hired when these managers are currently working at other fund(s) in the same family. Standard errors are in parentheses and ${ }^{*},{ }^{* *},{ }^{* *}$ indicate significance at the $10 \%, 5 \%$, and $1 \%$ levels respectively.

\begin{tabular}{|c|c|c|c|c|c|c|c|}
\hline & \multirow{2}{*}{$\begin{array}{l}\text { Hiring-Teammate } \\
\text { sample } \\
\text { (1) }\end{array}$} & \multicolumn{6}{|c|}{ Control sample } \\
\hline & & $\begin{array}{l}\text { All } \\
(2)\end{array}$ & $\begin{array}{c}\text { Diff } \\
(1)-(2)\end{array}$ & $\begin{array}{c}\text { Internal } \\
\text { (3) }\end{array}$ & $\begin{array}{c}\text { Diff } \\
(1)-(3)\end{array}$ & $\begin{array}{c}\text { External } \\
(4)\end{array}$ & $\begin{array}{c}\text { Diff } \\
(1)-(4)\end{array}$ \\
\hline Average $[t-24, t-1]$ & $\begin{array}{c}-0.112^{* * *} \\
(0.038)\end{array}$ & $\begin{array}{c}-0.124^{* * *} \\
(0.009)\end{array}$ & $\begin{array}{c}0.011 \\
(0.039)\end{array}$ & $\begin{array}{c}-0.117^{* * *} \\
(0.013)\end{array}$ & $\begin{array}{c}0.005 \\
(0.040)\end{array}$ & $\begin{array}{c}-0.131^{* * *} \\
(0.013)\end{array}$ & $\begin{array}{c}0.019 \\
(0.040)\end{array}$ \\
\hline Average $[t, t+23]$ & $\begin{array}{c}-0.189^{* * *} \\
(0.039)\end{array}$ & $\begin{array}{c}-0.108^{* * *} \\
(0.007)\end{array}$ & $\begin{array}{c}-0.081^{* *} \\
(0.040)\end{array}$ & $\begin{array}{c}-0.101^{* * *} \\
(0.010)\end{array}$ & $\begin{array}{c}-0.088^{* *} \\
(0.040)\end{array}$ & $\begin{array}{c}-0.117^{* * *} \\
(0.012)\end{array}$ & $\begin{array}{r}-0.072^{*} \\
(0.041)\end{array}$ \\
\hline Difference & $\begin{array}{r}-0.076 \\
(0.049)\end{array}$ & $\begin{array}{c}0.016 \\
(0.011)\end{array}$ & $\begin{array}{r}-0.092^{*} \\
(0.050)\end{array}$ & $\begin{array}{c}0.017 \\
(0.015)\end{array}$ & $\begin{array}{r}-0.093^{*} \\
(0.051)\end{array}$ & $\begin{array}{c}0.014 \\
(0.015)\end{array}$ & $\begin{array}{r}-0.090^{*} \\
(0.051)\end{array}$ \\
\hline
\end{tabular}


Since funds in the Hiring-Teammate sample have weaker governance (lower fraction of independent directors and lower fraction of institutional ownership) than those in the control sample, the difference in performance could come partly from these factors, as well as other fund and manager characteristics. Self-selection bias could be another possibility. To address these concerns, I use the propensity score matching method to match the most comparable fund-manager pair observations (closest propensity score) in the control group to those in the Hiring-Teammate sample. This method was pioneered by Rosenbaum and Rubin (1983) and has been used by Aggarwal et al. (2010), Fahlenbrach et al. (2011), Evans and Fahlenbrach (2012), etc.

\section{Table 5.4}

Propensity score matching and performance comparison for Hiring-Teammate managers.

Panel 1 reports multinomial logit estimates of the likelihood that managers are hired. There are four choices to hire managers: internally hiring those currently working in the family (Internal), externally hiring, rehiring those who used to work at this fund (Boomerang), or hiring those who used to be co-managers with these directors at other funds (Teammate). The base decision is externally hires. Column (1), (2), and (3) present coefficients from the estimate, while columns (4) and (5) show marginal effects with all predictors at their mean value. Tenure is logarithm of managers' tenure (in years) since they first appear in the database. Female dummy is equal tot 1 if manager is female. Master degree dummy is equal to 1 if managers have master degree. CFA dummy is equal to 1 if manager holds CFA certificate. Fraction ind. directors is the ratio of the number of independent board directors to board size. Frac. ins. ownership $[t-24, t-1]$ is the average fraction of funds owned by institutional investors for periods $[t-24, t-1]$, where $t$ is the period funds hire new managers. Fund size $[t-24, t-1]$ is logarithm of average fund net assets for periods $[t-24, t-1]$; Fund expense ${ }_{[t-24, t-1]}$ is fund average expense ratio for periods $[t-24, t-1] . \alpha_{[t-24, t-1]}$ is average net abnormal returns. $\sigma\left(\alpha_{[t-24, t-1]}\right)$ is standard deviation of net abnormal returns. Team dummy is equal to 1 if funds managed by team. $\beta_{M K T}, \beta_{S M B}, \beta_{H M L}$, and $\beta_{M O M}$ are Fama-French and Carhart factor loadings estimated using data within periods $[t-36, t-1]$. Then, these loadings, Fund size $[t-24, t-1], \sigma\left(\alpha_{[t-24, t-1]}\right)$, Fraction ind. directors, and Frac. ins. ownership are terciled and re-assigned values of 1,2 , and 3. Standard errors clustered at the family level are in parentheses and ${ }^{*},{ }^{* *},{ }^{* *}$ indicate significance at the $10 \%, 5 \%$, and $1 \%$ levels respectively.

(continued on next page) 
Table 5.4 (continued)

Panel 1: First stage

\begin{tabular}{|c|c|c|c|c|c|}
\hline \multirow[b]{2}{*}{ VARIABLES } & \multicolumn{3}{|c|}{ Coefficients } & \multicolumn{2}{|c|}{ Marginal effects } \\
\hline & $\begin{array}{l}\text { Teammate } \\
\text { (1) }\end{array}$ & $\begin{array}{c}\text { Boomerang } \\
\text { (2) }\end{array}$ & $\begin{array}{c}\text { Internal } \\
\text { (3) }\end{array}$ & $\begin{array}{c}\text { Teammate } \\
\text { (4) }\end{array}$ & $\begin{array}{c}\text { Boomerang } \\
\text { (5) }\end{array}$ \\
\hline \multicolumn{6}{|l|}{ Director-manager control variables: } \\
\hline Connection_IND ${ }_{t-1}$ & $\begin{array}{c}-2.098^{* * *} \\
(0.663)\end{array}$ & $\begin{array}{c}-9.642^{* * *} \\
(2.977)\end{array}$ & $\begin{array}{c}0.186 \\
(0.659)\end{array}$ & $\begin{array}{l}0.223^{* * *} \\
(0.070)\end{array}$ & $\begin{array}{l}0.172^{* * *} \\
(0.050)\end{array}$ \\
\hline Connection_DEP ${ }_{t-1}$ & $\begin{array}{r}-1.064 \\
(0.776)\end{array}$ & $\begin{array}{r}-1.773 \\
(1.811)\end{array}$ & $\begin{array}{c}0.240 \\
(0.673)\end{array}$ & $\begin{array}{c}0.079 \\
(0.049)\end{array}$ & $\begin{array}{c}0.052 \\
(0.040)\end{array}$ \\
\hline \multicolumn{6}{|c|}{ Percentage of directors have work with: } \\
\hline - Independent directors & $\begin{array}{c}-2.156^{* * *} \\
(0.452)\end{array}$ & $\begin{array}{c}-4.815^{* * *} \\
(0.518)\end{array}$ & $\begin{array}{c}-2.354^{* * *} \\
(0.671)\end{array}$ & $\begin{array}{c}0.019 \\
(0.034)\end{array}$ & $\begin{array}{l}0.127^{* * *} \\
(0.016)\end{array}$ \\
\hline - Inside directors & $\begin{array}{l}0.985^{* * *} \\
(0.322)\end{array}$ & $\begin{array}{c}-0.000 \\
(0.428)\end{array}$ & $\begin{array}{c}1.037^{*} \\
(0.622)\end{array}$ & $\begin{array}{c}0.019 \\
(0.041)\end{array}$ & $\begin{array}{c}-0.034^{* *} \\
(0.014)\end{array}$ \\
\hline \multicolumn{6}{|l|}{ Manager control variables: } \\
\hline Tenure $_{t-1}$ & $\begin{array}{c}-0.677^{* * *} \\
(0.127)\end{array}$ & $\begin{array}{c}-0.373^{* * *} \\
(0.119)\end{array}$ & $\begin{array}{c}-0.255 \\
(0.161)\end{array}$ & $\begin{array}{c}0.017^{*} \\
(0.009)\end{array}$ & $\begin{array}{l}0.026^{* * *} \\
(0.006)\end{array}$ \\
\hline Female dummy & $\begin{array}{l}0.721^{* * *} \\
(0.273)\end{array}$ & $\begin{array}{l}0.759^{* * *} \\
(0.288)\end{array}$ & $\begin{array}{c}0.001 \\
(0.362)\end{array}$ & $\begin{array}{r}-0.038^{*} \\
(0.023)\end{array}$ & $\begin{array}{c}-0.031^{* *} \\
(0.013)\end{array}$ \\
\hline Master degree dummy ${ }_{t-1}$ & $\begin{array}{c}0.149 \\
(0.223)\end{array}$ & $\begin{array}{l}0.809^{* * *} \\
(0.220)\end{array}$ & $\begin{array}{c}0.084 \\
(0.217)\end{array}$ & $\begin{array}{c}-0.012 \\
(0.016)\end{array}$ & $\begin{array}{c}-0.014 \\
(0.009)\end{array}$ \\
\hline CFA dummy $_{t-1}$ & $\begin{array}{c}0.054 \\
(0.230)\end{array}$ & $\begin{array}{c}0.495^{* *} \\
(0.240)\end{array}$ & $\begin{array}{c}0.270 \\
(0.222)\end{array}$ & $\begin{array}{c}0.006 \\
(0.015)\end{array}$ & $\begin{array}{c}-0.008 \\
(0.010)\end{array}$ \\
\hline \multicolumn{6}{|l|}{ Fund control variables: } \\
\hline Fraction ind. directors ${ }_{t-1}(\%)$ & $\begin{array}{l}0.379^{* * * *} \\
(0.129)\end{array}$ & $\begin{array}{c}0.278^{*} \\
(0.148)\end{array}$ & $\begin{array}{c}0.211 \\
(0.241)\end{array}$ & $\begin{array}{c}-0.007 \\
(0.017)\end{array}$ & $\begin{array}{c}-0.016^{* * *} \\
(0.006)\end{array}$ \\
\hline Frac. ins. ownership $[t-24, t-1](\%)$ & $\begin{array}{l}0.288^{* * *} \\
(0.107)\end{array}$ & $\begin{array}{r}0.231^{*} \\
(0.139)\end{array}$ & $\begin{array}{r}-0.318 \\
(0.201)\end{array}$ & $\begin{array}{c}-0.032^{* *} \\
(0.015)\end{array}$ & $\begin{array}{c}-0.011^{* *} \\
(0.005)\end{array}$ \\
\hline Fund size $_{[t-24, t-1]}$ & $\begin{array}{c}0.141^{*} \\
(0.085)\end{array}$ & $\begin{array}{c}-0.181 \\
(0.126)\end{array}$ & $\begin{array}{r}-0.057 \\
(0.174)\end{array}$ & $\begin{array}{r}-0.006 \\
(0.010)\end{array}$ & $\begin{array}{c}-0.002 \\
(0.004)\end{array}$ \\
\hline Fund expense $_{[t-24, t-1]}$ & $\begin{array}{c}-1.347 \\
(1.963)\end{array}$ & $\begin{array}{c}-0.694 \\
(2.793)\end{array}$ & $\begin{array}{c}-3.724 \\
(3.280)\end{array}$ & $\begin{array}{c}-0.144 \\
(0.213)\end{array}$ & $\begin{array}{c}0.061 \\
(0.082)\end{array}$ \\
\hline$\alpha_{[t-24, t-1]}$ & $\begin{array}{c}0.083 \\
(0.130)\end{array}$ & $\begin{array}{c}-0.013 \\
(0.173)\end{array}$ & $\begin{array}{c}0.014 \\
(0.169)\end{array}$ & $\begin{array}{c}-0.002 \\
(0.007)\end{array}$ & $\begin{array}{r}-0.003 \\
(0.006)\end{array}$ \\
\hline$\sigma\left(\alpha_{[t-24, t-1]}\right)$ & $\begin{array}{r}-0.213^{*} \\
(0.119)\end{array}$ & $\begin{array}{l}-0.453^{* * *} \\
(0.133)\end{array}$ & $\begin{array}{r}-0.179 \\
(0.170)\end{array}$ & $\begin{array}{c}0.005 \\
(0.011)\end{array}$ & $\begin{array}{l}0.012^{* *} \\
(0.005)\end{array}$ \\
\hline Team dummy $_{t-1}$ & $\begin{array}{c}0.152 \\
(0.158)\end{array}$ & $\begin{array}{l}0.860^{* * *} \\
(0.239)\end{array}$ & $\begin{array}{c}0.643^{* *} \\
(0.281)\end{array}$ & $\begin{array}{c}0.018 \\
(0.017)\end{array}$ & $\begin{array}{c}-0.016^{* *} \\
(0.008)\end{array}$ \\
\hline$\beta_{M K T}$ & $\begin{array}{c}0.122 \\
(0.095)\end{array}$ & $\begin{array}{l}0.267^{* *} \\
(0.133)\end{array}$ & $\begin{array}{c}0.130 \\
(0.123)\end{array}$ & $\begin{array}{c}-0.001 \\
(0.007)\end{array}$ & $\begin{array}{r}-0.007 \\
(0.004)\end{array}$ \\
\hline$\beta_{S M B}$ & $\begin{array}{c}0.123 \\
(0.083)\end{array}$ & $\begin{array}{l}0.216^{* *} \\
(0.104)\end{array}$ & $\begin{array}{l}0.370^{* * *} \\
(0.111)\end{array}$ & $\begin{array}{l}0.013^{* *} \\
(0.006)\end{array}$ & $\begin{array}{c}-0.007^{* *} \\
(0.004)\end{array}$ \\
\hline$\beta_{H M L}$ & $\begin{array}{c}-0.055 \\
(0.094)\end{array}$ & $\begin{array}{c}-0.073 \\
(0.103)\end{array}$ & $\begin{array}{c}0.070 \\
(0.132)\end{array}$ & $\begin{array}{c}0.007 \\
(0.008)\end{array}$ & $\begin{array}{c}0.002 \\
(0.004)\end{array}$ \\
\hline$\beta_{M O M}$ & $\begin{array}{c}0.006 \\
(0.091)\end{array}$ & $\begin{array}{c}0.119 \\
(0.117)\end{array}$ & $\begin{array}{r}-0.023 \\
(0.123)\end{array}$ & $\begin{array}{c}-0.003 \\
(0.009)\end{array}$ & $\begin{array}{c}-0.001 \\
(0.004)\end{array}$ \\
\hline Constant & $\begin{array}{l}4.365^{* * *} \\
(1.138)\end{array}$ & $\begin{array}{l}8.392^{* * *} \\
(1.199)\end{array}$ & $\begin{array}{c}2.064 \\
(1.283)\end{array}$ & & \\
\hline pseudo $R^{2}$ & 0.37 & & & & \\
\hline
\end{tabular}


Table 5.4 (continued)

Panel 2: Second stage

This panel presents fund's average net abnormal return (in percentages) two years before and after managers join the funds using matched samples. $t$ is the first month of managers' tenure at the new fund. Each fund_manager in Hiring-Teammate sample is matched with that in control sample that has the closest propensity score. In addition, the fund_manager that has a propensity score out of overlapping region between Hiring-Teammate and control groups will be dropped out. Standard errors are in parentheses and ${ }^{*},{ }^{* *},{ }^{* *}$ indicate significance at the $10 \%, 5 \%$, and $1 \%$ levels respectively.

Panel 2a: matched sample includes internal/external hires

\begin{tabular}{lccc}
\hline & Hiring-Teammate sample & Matched sample & Difference \\
& $(1)$ & $(2)$ & $(1)-(2)$ \\
\hline Average $[t-24, t-1]$ & $-0.113^{* * *}$ & $-0.159^{* * *}$ & 0.046 \\
& $(0.039)$ & $(0.033)$ & $(0.050)$ \\
Average $[t, t+23]$ & $-0.188^{* * *}$ & $-0.074^{* * *}$ & $-0.115^{* * *}$ \\
& $(0.039)$ & $(0.022)$ & $(0.044)$ \\
\hline Difference & -0.075 & $0.085^{* *}$ & $-0.160^{* *}$ \\
& $(0.049)$ & $(0.040)$ & $(0.062)$ \\
$\mathrm{N}$ & 249 & 249 & \\
\hline
\end{tabular}

Panel 2b: matched sample includes only internal hires

\begin{tabular}{lccc}
\hline & Hiring-Teammate sample & Matched sample & Difference \\
& $(1)$ & $(2)$ & $(1)-(2)$ \\
\hline Average $[t-24, t-1]$ & $-0.113^{* * *}$ & $-0.107^{* * *}$ & -0.006 \\
& $(0.039)$ & $(0.029)$ & $(0.048)$ \\
Average $[t, t+23]$ & $-0.188^{* * *}$ & $-0.087^{* * *}$ & $-0.101^{* *}$ \\
& $(0.039)$ & $(0.025)$ & $(0.046)$ \\
\hline Difference & -0.075 & 0.020 & -0.094 \\
$\mathrm{~N}$ & $(0.049)$ & $(0.035)$ & $(0.059)$ \\
\hline
\end{tabular}

Panel 2c: matched sample includes only external hires

\begin{tabular}{lccc}
\hline & Hiring-Teammate sample & Matched sample & Difference \\
& $(1)$ & $(2)$ & $(1)-(2)$ \\
\hline Average $[t-24, t-1]$ & $-0.117^{* * *}$ & -0.048 & -0.069 \\
& $(0.040)$ & $(0.048)$ & $(0.064)$ \\
Average $[t, t+23]$ & $-0.195^{* * *}$ & -0.044 & $-0.151^{* * *}$ \\
& $(0.040)$ & $(0.036)$ & $(0.054)$ \\
\hline Difference & -0.078 & 0.004 & -0.082 \\
$\mathrm{~N}$ & $(0.050)$ & $(0.040)$ & $(0.064)$ \\
\hline
\end{tabular}


In the first stage, the propensity score of fund $i$ hiring manager $m$ is estimated using the multinomial logit model. This is a four-choice model where fund $i$ can make a decision to hire one of the following managers: [1] Hiring-Teammate managers, [2] Boomerang managers, [3] internal managers, or [4] external managers (this is the base decision). Funds hiring internal and external managers in the control group will be used for the matching. In addition, I include the choice of hiring Boomerang managers because I will use the same propensity score matching method in the next section for the analysis of hiring Boomerang managers. The propensity score is the probability that firm $i$ with a given characteristics hires Hiring-Teammate managers with a given quality. Fund and manager characteristics used in the model are: duration of the connection between managers and directors before hiring, percentage of directors with whom managers are connected before hiring, manager tenure, gender, education (dummies for having master or CFA), the percentage of independent directors, average percentage of institutional ownership over the two years prior to hiring, logarithm of fund average past two-year total net asset (Fund size $\left.e_{[t-24, t-1]}\right)$, fund average expense ratio $\left(\right.$ Fund expense $\left.e_{[t-24, t-1]}\right)$, fund average past two-year net alpha $\left(\alpha_{[t-24, t-1]}\right)$, standard deviation of fund net alpha within two years prior to hiring $\left(\sigma\left(\alpha_{[t-24, t-1]}\right)\right)$, team dummy if funds managed by team or not, and Fama and French (1993) and Carhart (1997) 4-factor loadings estimated using data within 36 months before hiring. Panel 1 in Table 5.4 reports the estimated coefficients.

In the second stage, each fund-manager observation in the Hiring-Teammate sample is matched with one in the control sample that has the closest propensity score. In addition, 
fund-manager observation with a propensity score out of the overlapping region between Hiring-Teammate and control groups will be dropped out. Panel 2a compares fund average net alpha two years before and after managers join the funds between the Hiring-Teammate sample and matched sample that does not distinguish whether managers are internally or externally hired. Panel $2 \mathrm{~b}$ and $2 \mathrm{c}$ compare funds' performance using a matched sample that includes funds that hired either only internal or only external managers. The results show that funds that hire Hiring-Teammate managers perform significantly lower than funds that do not hire these managers by $0.12 \%$ per month. This value is much lower than that when using the non-matched sample. In addition, the difference in change in performance between pre- and post-turnover events is significantly lower $(0.16 \%)$.

\subsection{Fund performance when hiring Boomerang managers}

\subsubsection{Fund and manager performance during the first term}

Before studying the benefits of rehiring Boomerang managers, it is essential to learn how these managers performed during the first term at the funds that rehired them (called as Boomerang funds hereafter) as well as other funds, if any, they concurrently manage during that time. The former is the fund performance analysis, while the latter is the manager performance analysis. 


\section{Table 5.5}

Performance of Boomerang managers at the first employment.

Panel 1 reports the fund's average net abnormal return (in percentages) two years before and after managers left the funds. $t$ is the last month of Boomerang managers' first employment of the funds they are rehired, while it is the last month of non-Boomerang managers' employment of any other funds. In the matched sample, each fund in Boomerang sample is matched with 3 funds in control sample with the smallest value of $\left|\frac{\text { Fund size } e_{[t-23, t]}^{C O N}}{\text { Fund size } e_{[t-23, t]}^{B B M}}-1\right|+\left|\frac{F_{\text {und expense }}^{C O N}[t-23, t]}{\text { Fundexpense } e_{[t-23, t]}^{B B M}}-1\right|$, where $X_{[t-23, t]}^{B B M}$ and $X_{[t-23, t]}^{C O N}$ are the average value of $X$ in periods $[t-23, t]$ of Boomerang and control funds. In addition, their size and expense must be within $\pm 30 \%$ of those of the Boomerang fund. Panel 2 is similar to Panel 1 but at manager level. Monthly abnormal returns at manager level are weighted average abnormal returns of all funds managed by each manager, where the weights are fund's lagged total net assets divided by total number of managers in that fund. Standard errors are in parentheses and ${ }^{*},{ }^{* *},{ }^{* * *}$ indicate significance at the $10 \%, 5 \%$, and $1 \%$ levels respectively.

Panel 1: Fund net alpha (\%)

\begin{tabular}{|c|c|c|c|c|c|}
\hline & \multirow[b]{2}{*}{$\begin{array}{l}\text { Boomerang } \\
\text { (1) }\end{array}$} & \multicolumn{4}{|c|}{ Control sample } \\
\hline & & $\begin{array}{l}\text { Full sample } \\
\text { (2) }\end{array}$ & $\begin{array}{c}\text { Diff. } \\
(1)-(2)\end{array}$ & $\begin{array}{c}\text { Matched sample } \\
\text { (3) }\end{array}$ & $\begin{array}{c}\text { Diff. } \\
(1)-(3)\end{array}$ \\
\hline \multirow[t]{2}{*}{ Average $[t-23, t]$} & -0.033 & $-0.111^{* * *}$ & $0.077^{*}$ & $-0.112^{* * *}$ & $0.077^{*}$ \\
\hline & $(0.040)$ & $(0.008)$ & $(0.041)$ & $(0.020)$ & $(0.044)$ \\
\hline \multirow[t]{2}{*}{ Average $[t+1, t+24]$} & $-0.097^{* * *}$ & $-0.095^{* * *}$ & -0.002 & $-0.116^{* * *}$ & 0.026 \\
\hline & $(0.032)$ & $(0.007)$ & $(0.032)$ & $(0.018)$ & $(0.035)$ \\
\hline \multirow[t]{2}{*}{ Difference } & -0.064 & 0.016 & -0.080 & -0.005 & -0.051 \\
\hline & $(0.048)$ & $(0.010)$ & $(0.049)$ & $(0.026)$ & $(0.055)$ \\
\hline Observation & 347 & 7,602 & & & \\
\hline
\end{tabular}

Panel 2: Manager net alpha (\%)

\begin{tabular}{lccccc}
\hline & & \multicolumn{3}{c}{ Control sample } \\
\cline { 3 - 6 } & Boomerang & Full sample & Diff. & Matched sample & Diff. \\
& $(1)$ & $(2)$ & $(1)-(2)$ & $-0.050^{*}$ & $(1)-(3)$ \\
\hline Average $[t-23, t]$ & $0.085^{*}$ & $-0.100^{* * *}$ & $0.185^{* * *}$ & $0.137^{* * *}$ \\
& $(0.044)$ & $(0.010)$ & $(0.045)$ & $(0.029)$ & $(0.049)$ \\
Observation & 292 & 4,572 & & \\
\hline
\end{tabular}


First, in the fund performance analysis, I compare fund net alpha surrounding departure events, when managers left the funds, between funds in the Boomerang sample and those in the control group. Note that the control group in this subsection is different than that used for the other subsections. This control group consists of any fund-manager pair where the managers left the fund and the fund survives after their departures. There are 7,602 fund-manager pairs in the control sample. Panel 1 in Table 5.5 reports these comparisons. The first row presents the fund monthly average net alpha during the last two years of the manager's tenure. The second row reports fund monthly average performance within the next two years. The results show that prior to the turnover event, the average performance of Boomerang funds is $-0.03 \%$ (not statistically significant), while that of the control funds is significantly negative at $-0.11 \%$. It is also significantly lower than that of Boomerang funds. Fund performance after the departure events is the same for the two samples.

To reduce the characteristic effects on fund performance, I match only the three most comparable turnover events, in terms of funds size and expense, in the control sample to each turnover event in the Boomerang sample. Specifically, for each Boomerang turnover event, I will select the three funds in the control sample that have the smallest value

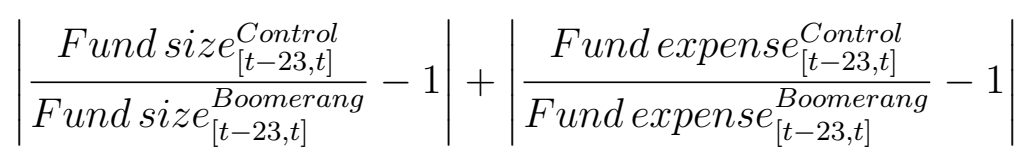

where $X_{[t-23, t]}^{\text {Boomerang }}$ and $X_{[t-23, t]}^{\text {Control }}$ are the average value of $X$ during periods $[t-23, t]$ of Boomerang and control funds; $t$ is the last month of manager employment. In addition, fund size and expense of matched funds must be within $\pm 30 \%$ of those of the Boomerang 
funds. Column (3) reports the performance of the matched sample. The difference in performance between Boomerang funds and matched funds is similar to that using the un-matched sample. Boomerang funds perform significantly better than non-Boomerang funds.

Lastly, in the manager performance analysis, since managers manage multiple funds at the same time, I will also compare the last two-year performance of all funds managed by Boomerang managers during their first term to that of all funds managed by non-Boomerang managers. Specifically, let $t$ be the last month manager $m$ works at fund $i$ in both samples. Note that $t$ is the last month Boomerang managers work at Boomerang funds in the first term. I collect all funds managed by manager $m$ during periods of $[t-23, t]$ and compute manager performance (net alpha) at each period following Berk et al. (2017)

$$
\alpha_{m t}=\frac{1}{\sum_{i \in \Omega_{m, t-1}} \frac{T N A_{i, t-1}}{N_{i, t-1}}} \sum_{i \in \Omega_{m, t-1}} \frac{T N A_{i, t-1}}{N_{i, t-1}} \alpha_{i t}
$$

where $\Omega_{m t}$ is the set of all funds managed by manager $m$ at time $t$, and $N_{i t}$ is the number of managers that manage fund $i$. Panel 2 shows that average monthly performance of Boomerang managers is significantly positive at $0.09 \%$, while that of non-Boomerang managers is significantly negative at $-0.1 \%$. In addition, they are significantly different from each other. I repeat the similar matching procedure used in the fund performance analysis to find matched managers. Boomerang managers outperform matched managers by $0.14 \%$ per month.

In sum, during the first term at the Boomerang funds, the Boomerang managers perform better not only at these funds but also at all the funds they manage during that time. These 
results suggest that these managers could have been promoted to higher positions or moved to the hedge fund industry. However, this paper does not focus on the post-turnover events, but rather on understanding how Boomerang managers perform during their first term.

\subsubsection{Fund performance during the second term}

Right before rehiring Boomerang managers, on average, $78 \%$ of current directors sat on the fund board for the periods when Boomerang managers were at their first term. In addition, these managers have tight connections with fund directors in term of duration of time and number of funds they have employed as mentioned in Section 5.1. Furthermore, these managers had good performance in their first tenure. It seems that bringing back these managers would be beneficial for investors. However, Table 5.6 suggests otherwise. The second row reports fund average net alpha during the first two years when managers join the funds. It shows that funds managed by Boomerang managers perform significantly lower by $-0.1 \%$ per month than those managed by non-Boomerang managers regardless of whether these managers are internally or externally hired. In addition, the difference in change in performance between pre- and post-turnover events is also significantly lower by $0.09 \%$.

Since fund and manager characteristics and self-selection bias might be the factors causing these differences in performance, I also use the propensity score matching technique to find matched hiring events in the control group for those in the Boomerang sample as we did in Section 5.3. Using the results of the first stage estimation at Panel 1 in Table 5.4 to 


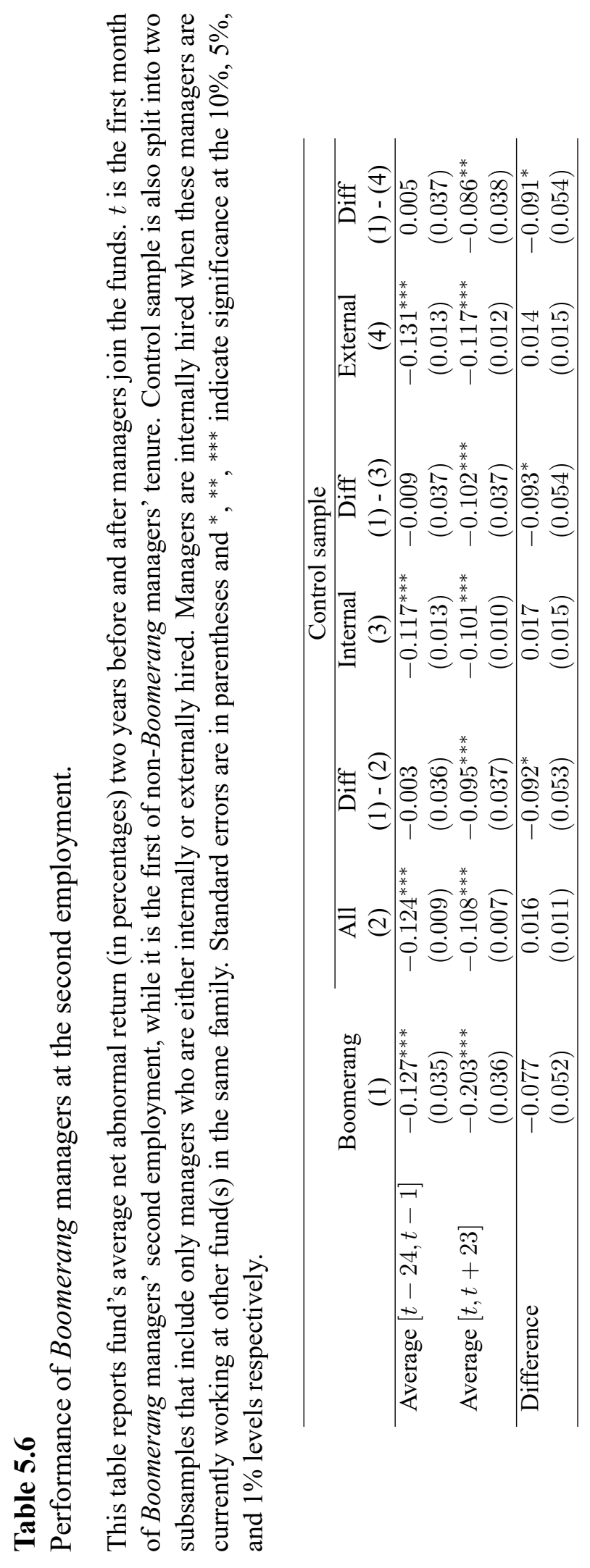


find matched fund-manager observations, Table 5.7 presents the performance comparison between the Boomerang sample and the matched samples. The matched sample includes either internal or external hires in Panel 1, includes only internal hires in Panel 2, and includes only external hires in Panel 3. The results show that funds managed by Boomerang managers are underperformed by $0.09 \%$ per month. In addition, the difference in change in performance between pre- and post-turnover events is both statistically and economically higher when we use the matching procedure. Similarly, the results are stronger if we compare the performance of funds hiring Boomerang managers to that of funds hiring either internally or externally, exclusively. 
Table 5.7

Propensity score matching and performance comparison for Boomerang managers at the second employment.

This table reports fund's average net abnormal return (in percentages) two years before and after managers join the funds using matched samples. Each fund-manager observation in Boomerang sample is matched with that in control sample that has the closest propensity score using results of the first stage estimation in Table 5.4. In addition, fund-manager that has propensity score out of overlapping region between Boomerang and non-Boomerang groups will be dropped out. $t$ is the first month of Boomerang managers' second employment, while it is the first of non-Boomerang managers' tenure. Standard errors are in parentheses and ${ }^{*},{ }^{* *},{ }^{* *}$ indicate significance at the $10 \%$, $5 \%$, and $1 \%$ levels respectively.

Panel 1: matched sample includes internal/external hires

\begin{tabular}{llcc}
\hline & $\begin{array}{c}\text { Boomerang } \\
(1)\end{array}$ & $\begin{array}{c}\text { Matched sample } \\
(2)\end{array}$ & $\begin{array}{c}\text { Difference } \\
(1)-(2)\end{array}$ \\
\hline Average $[t-24, t-1]$ & $-0.128^{* * *}$ & $-0.160^{* * *}$ & 0.032 \\
& $(0.035)$ & $(0.031)$ & $(0.047)$ \\
Average $[t, t+23]$ & $-0.203^{* * *}$ & $-0.112^{* * *}$ & $-0.091^{* *}$ \\
& $(0.036)$ & $(0.023)$ & $(0.044)$ \\
\hline Difference & -0.076 & 0.047 & $-0.123^{*}$ \\
& $(0.052)$ & $(0.040)$ & $(0.067)$ \\
$\mathrm{N}$ & 346 & 346 & \\
\hline
\end{tabular}

Panel 2: matched sample includes only internal hires

\begin{tabular}{llcc}
\hline & $\begin{array}{c}\text { Boomerang } \\
(1)\end{array}$ & $\begin{array}{c}\text { Matched sample } \\
(2)\end{array}$ & $\begin{array}{c}\text { Difference } \\
(1)-(2)\end{array}$ \\
\hline Average $[t-24, t-1]$ & $-0.128^{* * *}$ & $-0.134^{* * *}$ & 0.006 \\
& $(0.035)$ & $(0.026)$ & $(0.044)$ \\
Average $[t, t+23]$ & $-0.203^{* * *}$ & $-0.062^{* * *}$ & $-0.142^{* * *}$ \\
& $(0.036)$ & $(0.021)$ & $(0.041)$ \\
\hline Difference & -0.076 & $0.072^{* *}$ & $-0.148^{* *}$ \\
& $(0.052)$ & $(0.032)$ & $(0.061)$ \\
$\mathrm{N}$ & 346 & 346 & \\
\hline
\end{tabular}

Panel 3: matched sample includes only external hires

\begin{tabular}{llcc}
\hline & $\begin{array}{c}\text { Boomerang } \\
(1)\end{array}$ & $\begin{array}{c}\text { Matched sample } \\
(2)\end{array}$ & $\begin{array}{c}\text { Difference } \\
(1)-(2)\end{array}$ \\
\hline Average $[t-24, t-1]$ & $-0.131^{* * *}$ & $-0.187^{* * *}$ & 0.055 \\
& $(0.036)$ & $(0.034)$ & $(0.050)$ \\
Average $[t, t+23]$ & $-0.201^{* * *}$ & $-0.091^{* * *}$ & $-0.110^{* *}$ \\
& $(0.037)$ & $(0.024)$ & $(0.044)$ \\
\hline Difference & -0.070 & $0.095^{* * *}$ & $-0.165^{* *}$ \\
& $(0.053)$ & $(0.034)$ & $(0.066)$ \\
$\mathrm{N}$ & 338 & 338 & \\
\hline
\end{tabular}




\section{Chapter 6}

\section{Conclusions}

Using a data set of U.S. actively managed equity funds, this paper argues that the duration of the connection between fund independent directors and fund managers is one of the determinants of fund governance. I show that fund net abnormal returns decline by about $0.04 \%$ per year for each additional 1 -year connection between managers and independent directors.

The connection duration with independent directors also significantly increases manager's probability of survival at the funds, after controlling for fund past performance. For example, compared to managers who have a 1-year connection with fund directors, those with a 5 -year connection have higher survivor probability by $10 \%$ on average. This difference in survivorship decreases in fund governance quality, as proxied by the fraction of institutional ownership, and team size. Surprisingly, the positive relationship between connection duration and manager survivorship is still significant even when funds have a negative past 36-month net alpha. These results suggest that there is manager entrenchment when funds have weak governance, when managers are more senior, and when they have a 
long-term connection with fund independent directors.

Finally, newly hired managers who have long-term and tight connections with fund directors hurt investors. Specifically, funds underperformed by $1.1 \%$ to $1.4 \%$ per year when managers who are/were co-managers with fund directors or managers who used to work for these funds under the same directors were brought in. Using the propensity score matching method, these findings were compared to similar funds that do not hire these types of managers. This underperformance is both economically and statistically significant. 


\section{Bibliography}

Adams, J. C., Mansi, S. A., Nishikawa, T., 2010. Internal governance mechanisms and operational performance: Evidence from index mutual funds. Review of Financial Studies 23 (3), 1261-1286.

Adams, J. C., Nishikawa, T., Rao, R. P., 2016. Mutual fund performance, management teams, and boards. Journal of Banking and Finance pp. 1-11.

Aggarwal, R., Erel, I., Stulz, R., Williamson, R., 2010. Differences in governance practices between U.S. and foreign firms: Measurement, causes, and consequences. Review of Financial Studies 23, 3131-3169.

Berk, J. B., van Binsbergen, J. H., Liu, B., 2017. Matching capital and labor. Journal of Finance 72 (6), 2467-2504.

Bruynseels, L., Cardinaels, E., 2014. The audit committee: Management watchdog or personal friend of the CEO? Accounting Review 89 (1), 113-145.

Carhart, M. M., 1997. On persistence in mutual fund performance. Journal of Finance 52 (1), 57-82.

Chevalier, J., Ellison, G., 1999. Are some mutual fund managers better than others? Cross sectional patterns in behavior and performance. Journal of Finance 54, 875-899.

Chidambaran, N. K., Kedia, S., Prabhala, N. R., 2012. CEO-Director connections and corporate fraud. Working Paper .

Chu, J. S. G., Davis, G. F., 2016. Who killed the inner circle? The decline of the American corporate interlock network. American Journal of Sociology 122 (3), 714-754.

Crespi-Cladera, R., Pascual-Fuster, B., 2014. Does the independence of independent directors matter? Journal of Corporate Finance 28, 116-134.

Ding, B., Wermers, R., 2012. Mutual fund performance and governance structure: The role of portfolio managers and boards of directors. Working Paper . 
Elton, E. J., Gruber, M. J., Blake, C. R., 2001. A first look at the accuracy of the CRSP mutual fund database and a comparison of the CRSP and Morningstar mutual fund databases. Journal of Finance 56, 2415-2430.

Evans, R. B., Fahlenbrach, R., 2012. Institutional investors and mutual fund governance: Evidence from retail-institutional fund twins. Review of Financial Studies 25, 35303571.

Fahlenbrach, R., Minton, B. A., Pan, C. H., 2011. Former CEO directors: Lingering CEOs or valuable resources? Review of Financial Studies 24, 3486-3518.

Fama, E. F., French, K. R., 1993. Common risk factors in the returns on stocks and bonds. Journal of Financial Economics 33, 3-56.

Ferris, S. P., Yan, X. S., 2007. Do independent directors and chairmen matter? The role of boards of directors in mutual fund governance. Journal of Corporate Finance 13, 392420.

Fracassi, C., Tate, G., 2012. External networking and internal firm governance. Journal of Finance 67 (1), 153-194.

Guercio, D. D., Dann, L. Y., Partch, M. M., 2003. Governance and boards of directors in closed-end investment companies. Journal of Financial Economics 69, 111-152.

Hwang, B.-H., Kim, S., 2009. It pays to have friends. Journal of Financial Economics 93, $138-158$.

Khanna, V., Kim, E. H., Lu, Y., 2015. CEO connectedness and corporate fraud. Journal of Finance 70 (3), 1203-1252.

Meschke, F., 2007. An empirical examination of mutual fund boards. Working Paper .

Rosenbaum, P. R., Rubin, D. B., 1983. The central role of the propensity score in observational studies for causal effects. Biometrika 70, 41-55. 